\title{
Cold Atmospheric Plasma Manipulation of Proteins in Food Systems
}

\author{
Tolouie, Haniye; Mohammadifar, Mohammad Amin; Ghomi, Hamid; Hashemi, Maryam
}

\section{Published in:}

Critical Reviews in Food Science and Nutrition

Link to article, DOI:

10.1080/10408398.2017.1335689

Publication date:

2018

Document Version

Peer reviewed version

Link back to DTU Orbit

Citation $(A P A)$ :

Tolouie, H., Mohammadifar, M. A., Ghomi, H., \& Hashemi, M. (2018). Cold Atmospheric Plasma Manipulation of Proteins in Food Systems. Critical Reviews in Food Science and Nutrition, 58(15), 2583-2597.

https://doi.org/10.1080/10408398.2017.1335689

\section{General rights}

Copyright and moral rights for the publications made accessible in the public portal are retained by the authors and/or other copyright owners and it is a condition of accessing publications that users recognise and abide by the legal requirements associated with these rights.

- Users may download and print one copy of any publication from the public portal for the purpose of private study or research.

- You may not further distribute the material or use it for any profit-making activity or commercial gain

- You may freely distribute the URL identifying the publication in the public portal 


\section{Critical Reviews in Food Science and Nutrition}

\section{Cold Atmospheric Plasma Manipulation of Proteins in Food Systems}

\section{Haniye Tolouie, Maryam Hashemi , Mohammad Amin Mohammadifar \& Hamid Ghomi}

To cite this article: Haniye Tolouie, Maryam Hashemi, Mohammad Amin Mohammadifar \& Hamid Ghomi (2017): Cold Atmospheric Plasma Manipulation of Proteins in Food Systems, Critical Reviews in Food Science and Nutrition, DOI: 10.1080/10408398.2017.1335689

To link to this article: http://dx.doi.org/10.1080/10408398.2017.1335689

Accepted author version posted online: 14 Jun 2017.

\section{Submit your article to this journal \lceil}

III Article views: 30

Q View related articles ¿ك

View Crossmark data $\asymp$ 


\title{
Cold Atmospheric Plasma Manipulation of Proteins in Food Systems
}

Haniye Tolouie $^{\mathrm{a}}$, Maryam Hashemi ${ }^{\mathrm{b}}$, Mohammad Amin Mohammadifar ${ }^{\mathrm{c}}$, Hamid Ghomi ${ }^{\mathrm{d}}$

${ }^{a}$ Department of Food Science and Technology, Shahid Beheshti University of Medical Science, Tehran, Iran.

${ }^{\mathrm{b}}$ Microbial Biotechnology Department, Agricultural Biotechnology Research Institute of Iran (ABRII), AREEO, Agricultural Research, Education and Extension Organization (AREEO),

\section{Karaj, Iran}

${ }^{\mathrm{c}}$ Research Group for Food Production Engineering, National Food Institute, Technical University of Denmark, SøltoftsPlads, 2800, Kgs. Lyngby, Denmark

${ }^{\mathrm{d}}$ Laser and Plasma Research Institute, Shahid Beheshti University, Evin, 1983963113, Tehran,

\section{Iran}

Corresponding author at: Microbial Biotechnology Department, Agricultural Biotechnology

Research Institute of Iran (ABRII), Karaj, AREEO, Iran. PO Box: 31535-1897, Karaj, Iran E-

mail address: hashemim@abrii.ac.ir (M. Hashemi).

\begin{abstract}
Plasma processing has been getting a lot of attention in recent applications as a novel, ecofriendly, and highly efficient approach. Cold plasma has mostly been used to reduce microbial counts in foodstuff and biological materials, as well as in different levels of packaging, particularly in cases where there is thermal sensitivity. As it is a very recent application, the impact of cold plasma treatment has been studied on the protein structures of food and pharmaceutical systems, as well as in the packaging industry. Proteins, as a food constituent, play a remarkable role in the techno-functional characteristics of processed foods and/or the
\end{abstract}




\section{ACCEPTED MANUSCRIPT}

physico-chemical properties of protein-based films. At the same time, some proteins are responsible for reduction in quality and nutritional value, and/or causing allergic reactions in the human body. This study is a review of the influences of different types of plasma on the conformation and function of proteins with food origin, especially enzymes and allergens, as well as protein-made packaging films. In enzyme manipulation with plasma, deactivation has been reported to be either partial or complete. In addition, an activity increase has been observed in some cases. These variations are caused by the effect of different active species of plasma on the enzyme structure and its function. The level and type of variations in the functional properties of food proteins, purified proteins in food, and plasma-treated protein films are affected by a number of control factors, including treatment power, time, and gas type, as well as the nature of the substance and the treatment environment.

\section{Keywords}

Cold plasma; Protein structure; Functional properties; Enzymes; Physico-chemical properties; techno-functional properties. 


\section{ACCEPTED MANUSCRIPT}

\section{Introduction}

Plasma is considered as the fourth fundamental state of matter. It may be categorized as thermal or non-thermal plasma, depending on its density and electron temperature (Zhu et al., 2011). All types of plasma---including high, atmospheric, and low-pressure plasmas, have a broad spectrum of applications in different fields, such as textile (Huang et al., 2013; Malshe et al., 2013), electronics (He et al., 2013), life sciences (Pröfrock and Prange, 2012), packaging (Guillard et al., 2010; Pankaj et al., 2014a), dental applications (Hoffmann et al., 2013; Kim et al., 2014), sterilization (Lerouge et al., 2001; Moisan et al., 2002; Akitsu et al., 2005; Lee et al., 2006; De Geyter and Morent, 2012; Klämpfl et al., 2012; Kim et al., 2013; Ziuzina et al., 2013; Cui et al., 2016), plasma medicines (Weltmann et al., 2012; Laroussi, 2014), and food processing (Banu et al., 2012). Thanks to the special features of low-temperature (cold) atmospheric plasma technology---including cost-effectiveness, ability to achieve a moderate temperature in the vacuum-free systems, and flexibility in practice---many studies have recently been conducted on cold plasma applications (Oh et al., 2011). In different types of plasma, the formation of reactive species (especially oxygen, and nitrogen reactive species) can advance some chemical reactions, such as oxidation, cleavage, or polymerization reactions (Afshari and Hosseini, 2013; Schlüter et al., 2013; Pankaj et al., 2014a). In addition, ultraviolet irradiation is also reported in both the short and the long wavelength regions $(100--380 \mathrm{~nm})$ in the plasma treatment, which can cause photochemical reactions (Schlüter et al., 2013). Because of such functions due to the presence of reactive components, its potential applications in bioscience and food processing has increased in recent years. 


\section{ACCEPTED MANUSCRIPT}

Food proteins are one of the most important ingredients in the human diet due to their nutritional value and vital components, as they maintain or create the desired qualitative attributes in many types of foods (Cannon, 1945). In general, proteins have remarkable effects on the physicochemical profile, rheological behaviour, and textural and sensory properties of foods. 'Functional properties' of proteins are classically defined as the ability to form or stabilize gellike networks, films, foams, emulsions, and sols (Foegeding and Davis, 2011). The diversity in protein functionality is associated with their structure, size, configuration, surface characteristics, and also the extent and nature of their interaction with other food components, such as polysaccharides and lipids (Haque et al., 2016).

Most enzymes have protein-based structures that act as an accelerator/enhancer in chemical reactions. Enzyme catalysts are needed to make biochemical reactions possible (Zaks and Klibanov, 1984). Many enzymes such as protease, Lipase, amylase, and lactase currently have wide applications and future potential in the food industry. Enzymes play a significant role in food preservation; for example, egg-white lysozyme is generally accepted as an antimicrobial enzyme against clostridia spoilage (Hughey and Johnson, 1987; Roller, 1995). Although the maintenance of the activity of enzyme added to food for preservation can be a critical concern during processing, there are certain enzymes that can be involved in unwanted reactions, resulting in the loss of sensory and nutritional quality (Hendrickx et al., 1998). For such enzymes, it is especially important to prevent or restrict deleterious enzymatic reactions in order to provide a high-quality product with extended shelf life. The nutritional and functional attributes and activities in enzymes are closely associated with their amino acid composition and sequence, as well as their structural formation (Damodaran, 1994). 


\section{ACCEPTED MANUSCRIPT}

The presence of plasma reactive species can affect proteins and protein-based structures, such as enzymes. A number of recent papers (Takai, et al., 2012; Surowsky et al., 2013 and 2014; Tammineedi et al., 2013; Bußler et al., 2015; Mirsa et al., 2015; Zhang et al., 2015; Bahrami et al., 2016; Lee et al., 2016; Mirsa et al., 2016; Segat et al., 2016) have concentrated on the fundamental reactions between atmospheric-pressure plasma and proteins, particularly enzymes, in the model of food systems. They discuss the impacts of plasma on the activity and the structure of endogenous/exogenous enzymes, and on techno-functional properties of proteins. In this paper, we review some important aspects of cold plasma application for the manipulation of proteins in food systems as a possible alternative to the thermal treatment processes.

\section{Plasma definition, generation, and classification}

"Plasma" mainly consists of positive and negative ions, radicals, electrons, and excited or ground state of atoms, which results from subjecting a gas to an energy source (Conrads and Schmidt, 2000; Ramazzina et al., 2015). Energy is delivered in sequence to the electrons and the heavy species via collisions, leading to the destruction of chemical species. For instance, a molecule can become excited to the extent that it becomes dissociated (Moreau et al., 2008). The gases utilized in plasma can be air or noble gases like helium and argon, or a mixture of different types of gases in an appropriate ratio. The type of the applied gas plays a significant role in the formation of ionization products in plasma processing. For instance, the intermediate products of pure argon can be inert species or active/ionized argon particles. The majority of the species are made of dried air---including oxygen and nitrogen active species with an inconsequential content of trace gases (Niemira, 2012). The plasma energy source (such as thermal, nuclear, and electrical) and the amount of applied energy in the plasma are other determining factors that can 


\section{ACCEPTED MANUSCRIPT}

affect the temperature and density of the resulting electrons. Based on electron temperature and density, plasma is classified as high-temperature (thermal) and low-temperature plasma (nonthermal) (Surowsky et al., 2015). The limitations of thermal plasma include the energy efficiency, the high quenching effect of chemical reactions, and the operating at temperatures much higher than ambient temperature, which can impact their applicability to food products (Moreau et al., 2008).

In non-thermal (cold) plasma, the electron temperature (several ten thousand $\mathrm{K}$ ) is much higher than the massive gas temperature (below $310 \mathrm{~K}$ ) (Knorr et al., 2011). From the thermodynamic standpoint, this high difference in electron temperature and gas temperature is categorized as non-equilibrium condition (Misra et al., 2017). Non-thermal plasma can be generated by a variety of discharge sources at different pressure levels. In plasma system, the lower gas pressure results in a lower voltage needed for ionization. This intrinsic property of plasma raises the need for generating cold plasma technologies that operate under atmospheric pressure, and therefore require less power to generate active plasma (Conrads and Schmidt, 2000). Furthermore, cold plasma can be described by its generation technology, e.g. corona discharge, dielectric barrier discharge (DBD), atmospheric pressure plasma jets (APPJ), and microwave discharge (Fridman et al., 2005).

3. The prominent sources of atmospheric cold plasma

In this section, we briefly describe the prominent sources of atmospheric cold plasma (ACP) and their characteristics: 


\section{ACCEPTED MANUSCRIPT}

\subsection{Corona discharge}

Corona discharge utilizes a pair of inhomogeneous electrodes equipped with a high-voltage system for the ionizing of the gas ( $\mathrm{Li}$ et al., 2004). The corona is a type of localized emission that can be ignited with a relatively high electric field at atmospheric pressure. Discharge mainly occurs near the sharp edges or around the wires, where the electric field is large enough (Fridman et al., 2005). In corona, the total discharge volume is extensively larger than the volume affected by the corona action (Eliasson and Kogelschatz, 1991). The operating regimes and the structures of corona discharge in air, nitrogen, helium, and hydrogen-methane mixture from a point to a plate electrode configuration were studied by Anato et al. (2009). The corona discharge structure is spatially non-uniform and is affected by the geometry of the set up. From an industrial point of view, corona discharge receives a great deal of attention because it can be applied to bulk gases in the atmospheric or higher pressures at a low temperature (Bárdos and Baránková, 2010). Cold plasma is stable and in steady condition for a long period of time (Misra et al., 2017).

\subsection{Dielectric barrier discharges}

DBD was the most favoured cold atmospheric plasma source (Kogelschatz, 2003; Roth et al., 2005; Brandenburg, 2017). DBDs use a dielectric barrier to cover one or both of the electrodes in the discharge gap. DBD discharges---also known as silent discharges---are generally achieved at high voltages (1--100 kV) and frequencies between 0.05 and $500 \mathrm{kHz}$, to ignite the gas discharge without the formation of sparks (Bogaerts et al., 2002; Moreau et al., 2008). The desired voltage is applied to the one electrode side, while the other electrode is grounded. As a result, any free electron in the gap is accelerated, thus receiving enough energy to form ions. The DBD 


\section{ACCEPTED MANUSCRIPT}

discharge could operate in different flow regimes, including homogenous glow or filamentary regime (Misra et al., 2017). The electrode configuration for DBD can be concrete, flat, or flexible. The flexible electrode configuration has been utilized for the encapsulated plasma treatment of foodstuff (Yong et al., 2015).

\subsection{Atmospheric pressure plasma jets (APPJ)}

Winter et al. (2015) reviewed APPJ's new development and updates in APPJ design. APPJ is widely used discharge type plasma that consists of two electrodes without any dielectric cover over them. Pressure plasma jets play an increasingly important role in various plasma processing applications because of their ability to generate plasma that is not spatially bound or confined by electrodes (Laroussi and Akan, 2007). Ionized plasma gases pass through a nozzle and are then directed to the substrate. The electrode gap is about a few millimetres, while the exposure distance between the nozzle and the substrate can be in the centimetre range. These non-thermal plasma jet sources typically operate at voltages of 100--1000 V (Ehlbeck et al., 2010).

\subsection{Microwave discharge}

Microwave plasma transfers energy using electromagnetic oscillations at a frequency below that of the thermal radiation. Microwave plasma is produced in the frequency of $300 \mathrm{MHz}--10 \mathrm{GHz}$ (Bogaerts et al., 2002). Microwave plasma---one of the most suitable plasma sources---can be used for surface modification due to the low energy in the resultant plasma ions (Hirose et al., 1982; Stoffels et al., 2002; Kusano, 2009). An optimization study on the production of stable microplasma in air and argon by the use of $2.45 \mathrm{GHz}$ microwave excitation was conducted by Gregório et al. (2009). Although high power levels are often needed for plasma generation in 


\section{ACCEPTED MANUSCRIPT}

microwave systems, the waveguide dimensions may limit the size of the plasma reactor (Bárdos and Baránková, 2010).

\section{Effects of plasma on natural amino acids}

All proteins are made up of a linear sequence of natural amino acids. The effect of plasma

exposure on amino acids can generally be discussed under three major categories---health aspects, protein function and structure, and sensory characteristics. Amino acids are necessary for the growth, survival, and health of the human body, especially nutritionally essential amino acids that must be supplied by the food sources. For instance, methionine makes a crucial contribution to the metabolism of cells (Wu et al., 2013). Methionine is considered as a hydrophobic essential amino acid frequently found in the interior hydrophobic core (Brosnan and Brosnan, 2006). In some proteins, a fraction of the methionine residue is somewhat surfaceexposed. This renders them very susceptible to oxidation treatment.

The arrangement and quantity of amino acids determine the ultimate protein shape and function. For example, cysteine residue in proteins---by virtue of its capability to bond with other cysteine residues---plays a key role in the formation of disulphide bonds that are especially important in protein folding and stability (Brosnan and Brosnan, 2006). Some researchers claim that free amino acids participate directly in taste and also are indirectly involved in flavour development, because they are the precursors of many odorants (Jurado et al., 2007).

In regard to the aforementioned importance of amino acids in food processing and the human body, in this section, we review past research works and recent findings on the interactions between amino acids and plasma species. 


\section{ACCEPTED MANUSCRIPT}

\subsection{Role of plasma species and functional molecules}

In nonthermal plasmas, the modification of proteins is mainly initiated by reactions with reactive oxygen species (ROS) in combination with the synergistic effect of reactive nitrogen species (RNS) (Fig. 1). The minor roles of UV photons and positive or negative particles may also play a part (Perni et al., 2007). ROS---for instance superoxide radicals or hydroxyl radicals---seems to be the main contributor to the plasma antibacterial activity (Boudam et al., 2006; Gaunt et al., 2006). These active species can lead to etching, cross-linking of proteins, and oxidative reactions in protein building blocks, especially in the side chains of amino acid residues.

Previous studies show that ROS such as ${ }^{\circ} \mathrm{OH}$ can lead to significant changes in protein structure finally cause the cleavage of proteins into peptides. The course of the oxidation process is determined by the availability of $\mathrm{O}_{2}$ and $\mathrm{O}_{2}{ }^{--}$(superoxide anion radical) or its protonated form $\mathrm{HO}_{2}{ }^{\cdot}$ (Berlett and Stadtman, 1997). These types of reactions can affect the disulphide bonding state, as previously reported after exposing arginine vasotocin (a peptide model) by microwave plasma (Motrescu et al., 2011). The oxidation of sulphur amino acids is the dominant alteration of proteins during the DBD processing (Lackmann et al., 2015). The main pathway in sulphur-sulphur bond cleavage could be the addition of an oxygen and hydrogen atom (originated hydroxyl radical or other active species) to the sulphur-containing atoms to form RSH and RSO, leading to split-off protein parts.

Another possible pathway can be ascribed to the transfer of non-covalently bound RS or amino acid sequence or peptide pieces into plasma-treated solution, which causes acidified medium and accelerates the formation of acidic compounds (Takai et al., 2012). 


\section{ACCEPTED MANUSCRIPT}

The influence of a higher level of acidity on bactericidal capability induced by low-frequency discharge plasma was investigated by Chen et al. (2008) in treating E. coli. Effective inactivation was achieved in non-buffered purified water, as a result of the reduction of water $\mathrm{pH}$ of 7 to a $\mathrm{pH}$ of 3 (Chen et al., 2008). It was suggested that plasma acidification may involve the formation of nitrous acid (HNO2) and nitric acid (HNO3) from NO via NO2 (Marouf-Khelifa et al., 2006; Doubla et al., 2008). Bacteria inactivation using gaseous NO in a liquid phase was demonstrated by Ghaffari et al. (2006).

Another possible mechanism is the acidic $\mathrm{H}_{3} \mathrm{O}^{+}$ion formation as a consequence of the reaction between water molecules and hydrogen peroxide (H2O2) (Chen and Lee, 2008).

However, according to a previous study (Khan and Elia, 1991), the modification of amino acids results from the chemical reactions with plasma-active species in the atmospheric-pressure cold plasma, rather than chemical degradation by acidic $\mathrm{pH}$.

However, previous research works (Rumbach et al., 2013; Tresp et al., 2013) demonstrate that the higher protein inactivation efficiency could be seen in an aqueous solution rather than in a dried state. The barrier effect of the protein molecules in the upper layer of dried materials may limit the transition of plasma-generated photons RS in the sample, while the solution is exposed to RS homogeneously. Another reason might be the interaction of solution components with plasma species, which can contribute to the formation of secondary reactive species, which in turn can cause further protein inactivation.

\subsection{The chemical reactivity of amino acids against plasma}

The relative reactivity of all 20 natural amino acids in solution was assessed by Takai et al. (2014) using a competitive plasma treatment experiment (Takai et al., 2014). The results reveal 


\section{ACCEPTED MANUSCRIPT}

that the contents of methionine, cysteine, and aromatic amino acids were selectively reduced after plasma exposure. The highest reactivity among the amino acids was observed in methionine, cysteine, tryptophan, phenylalanine, and tyrosine. They observed that methionine can be rapidly oxidized by plasma treatment. In agreement with previous studies, it was suggested that the oxidation of methionine residues takes place faster than the over-oxidation of cysteine residues (Lackmann et al., 2015). Lackmann et al. (2013) investigated the ability of plasma processing in atmospheric pressure for GapDH (glyceraldehyde 3-phosphate dehydrogenase) inactivation. They suggest that cysteine is present in the active site oxidase after plasma exposure (Lackmann et al., 2013). In this case, some cysteine residues oxidase preferentially over others, indicating that the amino acid status in the protein conformation might determine the site of action of active plasma species to some extent.

DBD exposure inactivates RNase A by forming methionine sulfoxide. The subsequent overoxidation of cysteines follows the dissociation of disulphide linkages (Lackmann et al., 2015).

Irreversible sulphonation of disulphide-bonded cysteine in glutathione was identified by exposure to ROS (Deutsch et al., 1999). Consistent with a previous report, disulphide bond formation between the cysteine thiol groups was found to be feasible by the plasma exposure (Ke et al., 2010; Ke et al., 2013). Takai et al. (2014) suggest that the formation of disulphide bond and cysteine sulphonation may happen at the same time (Takai et al., 2014). Kuo et al. (2004) propose that reactive oxygen species, such as atomic oxygen or $\mathrm{OH}$ radicals may attack aromatic amino acids like tryptophan, which are sensitive to oxidation (Kuo et al., 2004).

Takai et al. (2012) report that the intrinsic fluorescence of tryptophan residues in a protein declined rapidly during plasma treatment (Takai et al., 2012). Breakdown of L-valine solution 


\section{ACCEPTED MANUSCRIPT}

following the treatment with direct dielectric barrier discharges plasma, resulting in the formation of products such as formic acid, acetone, acetic acid, and pyruvic acid. Comparably, as indicated by X-ray photoelectron spectroscopy (XPS), the exposure of L-alanine to direct Arplasma leads to the degradation of $\mathrm{COOH}$ and $\mathrm{CNH} 2$ groups, especially after being subjected to ions (Huque et al., 2013).

\section{The effect of plasma on the structure and function of proteins}

Proteins are biological molecules that have a wide range of functionality among all macromolecules. The physico-chemical characteristics of proteins in food systems demonstrate unique functional properties such as their ability to form gels, foams, emulsions, and films. Such diversity in protein functions is due to the uniquely defined structures and conformation. Each protein has a specific shape that is held together by covalent, ionic, and hydrogen bonds and other chemical interactions. Here, we describe the recent developments in the cold plasma application in the manipulation of food proteins.

\subsection{Techno-functional properties of proteins}

Proteins are natural polymers that are widely known as functional ingredients in food substances. They are a component of complicated natural foodstuff such as flour, or they can be isolated as functional ingredients like gelatins. Such molecular characteristics as chain length, branching, charge, flexibility, and hydrophobicity largely determine the functional properties in food matrices (McClements, 2006). The functional attributes can include water-holding capacity, ability to thicken solutions, gel-forming ability and the capability to form and stabilize emulsions or foams. 


\section{ACCEPTED MANUSCRIPT}

Table 1 provides a summary of the research findings in the area of improvement of the technofunctional properties of proteins using cold plasma. The unique properties of the dough and the baking quality of wheat are mainly affected by the structure and quantity of the gluten proteins (Becker et al., 2012). Bahrami et al. (2016) suggest that plasma treatment changed the protein molecular weights and their solubility due to oxidative reactions and consequently their waterbinding capacity and their ability to form the gluten network (Bahrami et al., 2016). Treated wheat flour proteins had larger molecular weight fractions and lower monomers and proteins, including albumin and globulin fractions, resulting in enhanced dough strength. These results are confirmed by a previous work by Misra et al. (2015), who reported changes in the modulus of elasticity, and the viscosity of strong wheat flour. The alteration of rheological properties could be related to the enhanced disulphide bonds between gluten in subunits after plasma treatment. The results are highly affected by input voltage and the time of exposure (Misra et al., 2015).

The effect of ACP treatment on the techno-functionality of protein from Pisum sativum was investigated by Bußler et al. (2015). They observed $113 \%$ and $116 \%$ increase in the water and fat-holding capacities of pea flour after exposure to atmospheric cold plasma for up to 10 minutes. The results of fluorescence measurements confirmed the incidence of conformational alteration, which can be used to describe the observed effects on the techno-functional properties of ACP-treated pea flour fractions.

In a recent study, the effect of ACP treatment was investigated for whey protein isolate (WPI) solutions during treatment times ranging from 1 to 60 minutes (Segat et al., 2015). A small but significant increase in surface hydrophobicity index was observed until 15 minutes of treatment due to the slight oxidation in WPI after treatment. Oxidation in WPI modified the side-chain of 


\section{ACCEPTED MANUSCRIPT}

amino acid residues, which in turn resulted in an increase in carbonyl content and the surface hydrophobicity. Moreover, the strong oxidation of sulphur-containing amino acid side chains--specially cysteine amino acids or the aggregation among proteins---induced the loss of free SH groups. It was also reported that foaming improved within 15 min of exposure; however, following this period, it was reduced significantly although the foam stability increased. The reason could be the protein aggregation, based on the free SH group analysis, the size distribution test, and the high-performance liquid chromatography results. This kind of information is significant, as a better understanding of the fundamental interactions can then be used to design plasma systems with appropriate conditions that will achieve maximum efficiency. However, the combination of factors such as the plasma source, gas type, applied voltage, and substrate state plays an important role.

\subsection{Physical and mechanical properties of protein based films}

Natural products based on biopolymers, like proteins, have received a great deal of attention for biodegradable eco-friendly packaging in a bid to reduce the use of synthetic polymers (Ressouany et al., 1998). Proteins are complex molecules that are composed of polymers of 20 natural monomers. Proteins are related to a broad variety of functionality in foodstuff, especially a high binding potential between molecules (Cuq et al., 1997). In addition, protein films can improve the nutritional status of foods (Gennadios and Weller, 1990) and offer a high potential for forming various linkages and bonds at different sites (Bourtoom, 2009). Many reports have been published on the improved barrier and the mechanical properties of edible protein-based films by altering the properties of proteins using chemical and enzymatic treatments, in combination with hydrophobic materials or polymers, or by using a physical method (Bourtoom, 


\section{ACCEPTED MANUSCRIPT}

2009; Zhang and Mittal, 2010; Wihodo and Moraru, 2013). Regarding the interactions between plasma and proteins, plasma-induced chemical protein modification may have contributed to the variation in the physical and mechanical characteristics of food proteins, for instance zein, caseinate, soy protein isolate, and whey protein, which can be used as components of films and coatings (Table 2).

Pankaj et al. (2014c) reported that the surface roughness and hydrophilicity of the zein film could increase after plasma exposure. Similar increases have also been observed for sodium caseinate film (Pankaj et al., 2014b). Improvement in the hydrophilicity of the films can be associated with surface oxygenation after plasma treatment (Liu et al., 2004; Pankaj et al., 2014c). The increase in the ratio of oxygen to carbon atoms indicated that new oxygen-containing groups may form on the film surface (Pankaj et al., 2014b), leading to a change in the hydrophobic character to become increasingly hydrophilic (Sparavigna, 2008).

Previous studies show that, depending on the gas source of plasma, various functional groups such as carboxylic acid, amide bonds, and hydroxyl can be introduced to the surface of polymers (Desmet et al., 2009; Morent et al., 2011), which may eventually be effective in increasing the flexibility of the polymer. Oh et al. (2016) suggest that elongation and oxygen barrier property of defatted soybean meal (DSM) film can increase, following plasma treatment for 15 minutes at $400 \mathrm{~W}$. As a result, plasma exposure limited the oxygen availability in the DSM packaging film, resulting in the retardation of lipid oxidation of smoked salmon during storage at $4{ }^{\circ} \mathrm{C}$ (Oh et al., 2016). As discussed earlier, the presence of radicals on the film surface can form cross-linked polymer networks (Stutz et al., 1990), which results in the reduction of the network free volume and limits the $\mathrm{O}_{2}$ permeability of the film (Perez-gago and Krochta, 2001). This presumption was 


\section{ACCEPTED MANUSCRIPT}

further supported by the research findings showing a reduction in $\mathrm{O} 2$ barrier property in polymer by Ar-induced cross-linking (Houston et al., 2002). Other researchers suggest that cold plasma treatment may alter the solubility, but not the diffusivity, of water molecules, so that the bulk property of water vapor permeability may remain unchanged (Shriver and Yang, 2011; Oh et al., 2016). Pankaj et al. (2014) found that the intensity of the amide II band increased after DBD plasma treatment due to the occurrence of a shift from a $\beta$-sheet structure to an $\alpha$-helical configuration and the formation of more extensive hydrogen bonding between the proteins, leading to a reduction in the non-bonded peptide groups in the zein films (Pankaj et al., 2014c). In contrast, the FTIR spectrum results of the plasma-treated sodium caseinate film showed no significant changes in the peptide linkages and the helical structure of the protein (Pankaj et al., 2014b).

Over recent decades, some researchers have investigated the application of encapsulation for functional food components and drugs in the suitable edible delivery system (Dai et al., 2005; McClements et al., 2009; deVos et al., 2010; Tavares et al., 2014). A large diversity of food proteins (for example whey protein, casein, gelatin, wheat gluten, and myosin) is accessible as building blocks in the formation of delivery systems (McClements et al., 2009). Previous studies indicate that the biocompatibility and release capability of proteins are closely related to their molecular properties, including structural properties, conformational characteristics, and thermal stability (Mitragotri et al., 2014; McClements et al., 2009). As discussed before, some studies have demonstrated that ACP exposure can selectively alter the protein conformation and function, depending on biological origin, plasma type, and treatment condition. However, there is still a lack of investigation on the possible benefits of ACP treatment for improving the 


\section{ACCEPTED MANUSCRIPT}

encapsulation efficiency. Zhu et al. (2016) observed that thermal stability, electrical properties, and mechanical strength of drug-encapsulated nanoparticles are ameliorated by the impact of ACP. Hasirci et al. (2010) suggest that plasma exposure can lead to the higher hydrophilicity of poly D, L-lactide-co-glycolide (PLGA) films and consequently enhanced cell adhesion. The authors suggest that ACP application can contribute to encapsulation systems by changing the molecular properties of proteins, subsequently leading to higher encapsulation loading efficiency and delivery response.

\subsection{Enzyme structure and function}

Enzymes are biocatalysts that are able to manipulate all the main groups of biomolecules found in foodstuff. In many cases, enzymatic activity should be considered for product shelf life extension. Several attempts have been made earlier to improve food shelf life using cold plasma. The selected relevant researches are listed in Table 3.

Segat et al. (2016) evaluated the effect of dielectric barrier discharge plasma on the alkaline phosphatase activity of milk (Segat et al., 2016). Following the ACP treatments, regardless of the voltage applied after 120 seconds of treatment, the enzyme activity decreased by around 45-$50 \%$; after 180 seconds of exposure, the activity was reported to be below $10 \%$. Fridman et al. (2008) show that plasma affects proteins quite selectively. They also report the influence of plasma on trypsin activity, where the enzymatic activity of trypsin dropped to about zero after 10--15 seconds of ACP exposure (Fridman et al., 2008). According to Surowsky et al. (2013), 180 seconds of treatment can reduce about $90 \%$ of the polyphenoloxidase (PPO) activity, whereas peroxidase (POD) was not as sensitive as PPO, and the enzymatic activity decreased by about $85 \%$ after 240 seconds of treatment. The PPO activity was reduced significantly following 


\section{ACCEPTED MANUSCRIPT}

the addition of low levels of oxygen to argon compared to its activity while using pure argon. Tappi et al. (2014) observed up to about $42 \%$ linear reduction of the PPO residual activity in freshly cut apples by increasing the exposure time to 10, 20, and 30 minutes in the applied DBD system. The inactivation of PPO and POD enzymes in freshly cut apples and potatoes by microwave plasma during 10 minutes of plasma treatment has been investigated by Bußler et al. (2016). They report that the activity was reduced by about $62 \%$ and $77 \%$ in freshly cut apples and potatoes, respectively.

Zhang et al. (2015) investigated the possibility of the inactivation of lactate dehydrogenase (LDH) enzyme solutions by the helium-oxygen cold DBD plasma in two types of exposure (direct and indirect). Regardless of the treatment mode, the LDH activity decreases with the increase in treatment time. However, compared to the indirect treatment, a faster reduction rate in LDH activity was observed in the direct exposure for the exact time. This may be due to the diversities in the reactive species (RS) in both modes. They suggest that in the indirect mode, the long-lived RSs, such as $\mathrm{H}_{2} \mathrm{O}_{2}$, and $\mathrm{O}_{3}$ in the solution, play a major role in the plasma inactivation. However, in the direct treatment, in addition to the mentioned RS, the short-lived RSs such as $\mathrm{OH}^{*}$ and $\mathrm{O}_{2}$ as well as UV may be related to the enzyme inactivation of ACP. Pankaj et al. (2013) studied the effects of treatment time and voltage of the DBD plasma process on the activity of tomato peroxidase (Pankaj et al., 2013). They observed that the enzymatic activity decreased with both treatment time and voltage. The interaction between voltage and time was also significant. Between these two variables, the influence of voltage on inactivation rates was more pronounced. 


\section{ACCEPTED MANUSCRIPT}

Although in the majority of research studies, cold plasma leads to inactivation of enzymes, an increase in enzymatic activity is also reported in some cases. El-Aziz et al. (2014) studied the effect of the atmospheric pressure plasma jet on Plodiainterpunctella for insect control. They investigated antioxidant enzymatic activities, catalase glutathione S-transferase, and lipid peroxidase as markers of the oxidative stress in the body tissues of Indian meal moth larvae. Treatment with 15 pulses at a distance of $11 \mathrm{~cm}$ from the jet nozzle significantly increased the activity of catalase and lipid peroxide. No change in glutathione peroxidase was observed after 24 hours. Excessive oxidative damage led to an enhanced regulation of antioxidants regarding the insects' physiological adaptations and resistance. Li et al. (2011) examined the effect of the radio-frequency atmospheric-pressure plasma jet on the lipase activity originating from Candida rugosa (Type VII, L-1754) (Li et al., 2011). In this experiment, in the presence of Helium as the plasma working gas, the measured enzymatic activity of the lipase enhanced by increasing the plasma treatment time up to 50 seconds. The treatment did not affect the activity of the lipase in the lipase-buffer mixture. Chen et al. (2016) reported up to $162 \%$ increase in the activity of $\boldsymbol{\alpha}$ amylase in brown rice treated by low-pressure plasma at $3 \mathrm{kV}$ power input over 24 hours of germination (Chen et al., 2016). This result is in agreement with the findings of Lee et al. (2016). Puač et al. (2014) also found that the activity of superoxide dismutase (SOD) and catalase (CAT) enzymes increased following the exposure of carrot cells to atmospheric radio-frequency plasma. Therefore, this may be true if the cells were not lethally damaged. The inactivation/activation of enzymes when they are exposed to plasma mainly depends on the ability of the defence system to confront stress-induced RS (Puač et al., 2014). 


\section{ACCEPTED MANUSCRIPT}

It is noteworthy that any kind of enzymatic activity variation---regardless of the positive or negative effects---results from the modification of secondary and tertiary structures and changes in sensitive amino acids ( $\mathrm{Li}$, Wang, 2011). Figure 2 schematically summarizes the key steps for the enzyme inactivation by cold plasma.

Table 4 shows several findings of changes in the protein structure after exposure to cold plasma.

The study by Deng et al. (2007) reports that exposure of bovine serum albumin to atmosphericpressure glow discharge plasma degraded protein integrity (Deng et al., 2007). The possible suggested mechanisms for enzyme inactivation relied on the works done on egg white lysozyme as an enzyme model in an aqueous solution, using a low frequency helium plasma jet system, as suggested by Takai et al. (2012). In their study, mass spectroscopy, circular dichroism, and fluorescence measurement were used to examine the structural changes of lysozyme. The results indicate that the low frequency plasma jet modifies some amino acid residues and unfold the secondary structure of lysozyme. These alterations are mainly caused by the action of reactive oxygen and nitrogen species, which could oxidize reactive amino acids such as cysteine, aromatic rings of phenylalanine, tyrosine, and tryptophan and as a sequence change the secondary and tertiary structures of the enzyme configuration. Segat et al. (2016) investigated the pattern and extent of changes in the structure of alkaline phosphatase through circular dichroism studies and chemometric analysis. They found that inactivation could happen due to the loss of $\alpha$-helical and $\beta$-sheet secondary structures of the protein (Segat et al., 2016). The reason for the loss of lactate dehydrogenase (LDH) activity was investigated by circular dichroism and dynamic light scattering (Zhang et al., 2015). There was a sharp decrease in the turns and $\boldsymbol{\alpha}$-helix structures with an increase in the treatment time, whereas the percentage of random areas 


\section{ACCEPTED MANUSCRIPT}

and the amount of $\beta$-sheet contents increased remarkably, indicating that the secondary structure of the LDH enzyme was altered by the plasma. This result was in agreement with those reported by Surowsky et al. (2013) that simultaneous reduction of $\alpha$-helix structure and increase of $\beta$ sheet content can be attributed to the inactivation of peroxidase and polyphenol oxidase in a model food system, exposed to cold plasma treatment, which has been confirmed by circular dichroism and tryptophan fluorescence measurements (Surowsky et al., 2013). The tryptophan fluorescence measurements were considered as a pointer of oxidation reactions, the following modification in the three-dimensional structure, and the conformation of proteins.

However, the induced plasma changes on enzymes may be temporary, since the alterations in the enzyme structure tend to partially recover to an untreated state upon storage. Partial recovery in the LDH structure, which was treated by 300 seconds of plasma exposure, was reported after 24 hours of storage (Zhang et al., 2015). The reason could be the unique properties of each protein, which cause different sensitivity to plasma treatment. Such reports underlining the application of cold plasma in the enzyme field would require careful design to be useful for incorporation in food processes with a specific purpose. However, information about changes in the treated enzymes function and structure during the time still remains limited.

\section{Food allergenicity}

Food allergy has been a rising phenomenon for a long time and is considered a public health issue, especially in developed countries. A great number of food allergens are proteins or watersoluble glycoproteins with a molecular weight range 10--70 kDa (Besler, 2001).

Antibodies, namely immunoglobulin E (IgE), are an immunoglobulin subclass produced by the immune system. They are capable of binding to the allergens at a specific site (epitope), resulting 


\section{ACCEPTED MANUSCRIPT}

in various immunologic reactions. Changes in protein configuration can make changes in epitopes to the extent that they can no longer be identified by $\operatorname{IgE}$ antibodies or give any clue to immune response (Shriver and Yang, 2011).

Recent studies indicate that cold plasma has a potential for reducing the immunoreactivity of wheat and shrimp proteins (Nooji, 2011; Shriver, 2011). Meinlschmidt et al. (2016) investigated the impact of ACP on soy immuno-reactivity to control soy allergy (Meinlschmidt et al., 2016). Following the cold plasma, a reduction in protein intensity bands corresponding to major soy allergens (i.e. $\beta$-conglycinin (Gly m5) and glycinin (Gly m6)) was observed. Moreover, soy immunoreactivity was lost by up to nearly $100 \%$. These findings were revealed by SDS-PAGE analysis and Sandwich ELISA assessment respectively. Shriver (2011) found a remarkable decrease in the allergenicity of shrimp tropomyos by up to $76 \%$ due to air-generated DBD plasma (30 Kv, $60 \mathrm{~Hz}$, five minutes) (Shriver, 2011). Nooji (2011) also reported reduction in wheat allergenicity up to $37 \%$ after five minutes of applying direct DBD plasma with $30 \mathrm{kV}$ input power (Nooji, 2011). In contrast to the above studies, Tammineedi et al. (2013) observed no alteration in the antibody-binding capability of $\alpha$-casein and whey solution as major milk protein allergens after exposure to plasma afterglow (Tammineedi et al., 2013). Based on the report by Besler et al., several processing technologies may change food allergenicity caused by immunoglobulin E antibody (Besler et al., 2001). However, the influence of ACP on the proteinaceous inhibitors that exert the negative nutritional effects has not been investigated yet.

\section{Challenges and future research prospect}

Nowadays, the majority of procedures performed to change the protein activity or functions are based on thermal processing. However, recently, cold plasma has received a great deal of 


\section{ACCEPTED MANUSCRIPT}

attention as a novel nonthermal approach to modify protein or proteinaceous matters in a desired manner. Recent studies show a variety of plasma applications in the field of inactivation of deteriorating enzymes, improvement of physical and mechanical characteristics of films, and techno-functional characteristics of food components, as well as a reduction in allergenicity arising from food. There are multiple known mechanisms that can affect protein. However, the most important reason may be the alteration in protein conformation induced by plasma reactive species. The cleaved peptide bonds, oxidized amino acid side residuals, and form the protein-protein cross-linkages. These are examples of changes presumably resulting in the destruction of the protein structure. Based on our literature reviews, the research on the proposed mechanisms of interaction of cold plasma species and proteins is limited. There is great potential for further investigation on the improvement of understanding of these mechanisms in molecular scale and the development of kinetics of reactions. It should be considered that the chemistry of cold plasma is complex. For example, plasma in humid air consists of more than 75 species (Misra et al., 2016). This large number of species will lead to nearly 450 reactions (Kossyi et al., 1992). The chemistry of plasma can change depending on the gas mixture and the applied voltage. Utilizing the cold plasma technology in a large scale will require monitoring and controlling the plasma chemistry. The rheology and thermodynamic of plasma is another important aspect that require intensive modelling and research works. Misra et al. (2017) make use of Boltzmann equation for species combined with Navier--Stokes equations for the gas flow to understand the rheology of cold plasma. These equations include coefficient that can be estimated using experimental data. Resolving these equations will require computational fluid dynamic (CFD) tools. The combination of experimental findings and CFD results will help in the great 


\section{ACCEPTED MANUSCRIPT}

understanding of impact of the geometry, gas mixture and voltage on the efficiency of cold plasma and design of the most efficient system. This research area is very immature and further investigations are required.

Plasma can destruct microorganisms; therefore, it can be used as a surface cleaning tool for the removal of disinfections and also for cold sterilization. Despite the extensive research on the inactivation of microorganisms by cold plasma and their large-scale applications in biomedical sectors (Soloshenko et al., 2000; Moisan et al., 2001 and 2002), the studies on the inactivation of enzymes by using cold plasma are still limited to the small or lab-scale. Most of these studies have been performed under simplified conditions in a buffer environment. These researchers have demonstrated successful inactivation of enzymes in a short period of time. However, these results must be validated in real food systems before coming to any conclusion. There are demands for studies to be performed on the possible changes in the activity of enzyme during the storage of treated material with cold plasma (Zhang et al., 2015). The storage conditions need to be set to ensure that the enzyme activity is not recovered. This aspect has been less attended in the previous research works and requires further investigations. The changes made by plasma to the formulation of food recipes or conformation of food components could have unforeseen consequences on the final product quality (Pinela and Ferreira, 2015) and safety, as this would result in the temporary or permanent removal of some protective effects such as the lowering of water activity and reduction in antioxidant capacity. Accordingly, there is still a need for more comprehensive studies on the consequences of plasma protein manipulation in both in vitro and in vivo conditions to ensure the health of food supplies. It is especially remarkable in food products that claim to have high nutritional value and healthy properties. 


\section{ACCEPTED MANUSCRIPT}

The cost aspect of cold plasma treatment is still unclear. This cost includes both operating and capital costs to set up a cold plasma technology for a large-scale treatment process. This is due to the fact that the success of plasma treatment technology is eventually dependent on its economic viability. This seems to be a great prospect for future research. It is also very interesting to compare the cost and effect of plasma treatment with those of thermal treatment as a commonly used technique. 


\section{ACCEPTED MANUSCRIPT}

\section{References}

Afshari, R. and Hosseini, H. (2013). Non-thermal plasma as a new food preservation method, Its present and future prospect. Journal of Paramedical Sciences.5:116-120.

Akitsu, T., Ohkawa, H., Tsuji, M., Kimura, H.and Kogoma, M. (2005). Plasma sterilization using glow discharge at atmospheric pressure. Surface and Coatings Technology.193:29-34.

Antao, D. S., Staack, A. D., Fridman, A. and Farouk, B. (2009). Atmospheric pressure dc corona discharges: operating regimes and potential applications. Plasma Sources and Science Technology.18:035016.

Bahrami, N., Bayliss, D., Chope, G., Penson, S., Perehinec, T, and Fisk, I.D. (2016). Cold plasma: A new technology to modify wheat flour functionality. Food chemistry. 202:247-53.

Banu, M.S., Sasikala, P., Dhanapal, A., Kavitha, V., Yazhini, G. and Rajamani, L. (2012). Cold plasma as a novel food processing technology. International Jornal of Emerging trends in Engineering and Development. 4:803-18.

Bárdos, L. and Baránková, H. (2010). Cold atmospheric plasma: Sources, processes, and applications. Thin Solid Films. 518:6705-13.

Becker, D., Wieser, H., Koehler, P., Folck, A., Mühling, K. and Zörb, C. (2012). Protein composition and techno-functional properties of transgenic wheat with reduced $\alpha$-gliadin content obtained by RNA interference. Journal of Applied Botany and Food Quality. 85:23-33.

Berlett, B.S. and Stadtman, E.R. (1997). Protein oxidation in aging, disease, and oxidative stress. Journal of Biological Chemistry. 272:20313-6.

Besler, M. (2001). Determination of allergens in foods. TrACTrends in Analytical Chemistry. 20:662-72. 


\section{ACCEPTED MANUSCRIPT}

Besler, M., Steinhart, H. and Paschke, A. (2001). Stability of food allergens and allergenicity of processed foods. Journal of Chromatography B: Biomedical Sciences and Applications. 756:207-28.

Bogaerts, A., Neyts, E.,Gibels, R. and van der Mullen, J. (2002). Gas discharge plasmas and their applications. Spectrochimica Acta Part B: Atomic Spectroscopy. 57:609-658.

Boudam, M., Moisan, M., Saoudi, B., Popovici, C., Gherardi, N. and Massines, F. (2006). Bacterial spore inactivation by atmospheric-pressure plasmas in the presence or absence of UV photons as obtained with the same gas mixture. Journal of Physics D: Applied Physics. 39:3494. Bourtoom, T.(2009) Edible protein films: properties enhancement. International Food Research Journal. 16:1-9.

Brandenburg, R. (2017). Dielectric barrier discharges: progress on plasma sources and on the understanding of regimes and single filaments. Plasma Sources Science and Technology. 26: 053001.

Brosnan, J.T. and Brosnan, M.E. (2006). The sulfur-containing amino acids: an overview. The Journal of nutrition. 136:1636S-1640S.

Bußler, S., Ehlbeck, J. and Schlüter O.K. (2016). Pre-drying treatment of plant related tissues using plasma processed air: Impact on enzyme activity and quality attributes of cut apple and potato. Innovative Food Science \& Emerging Technologies. 40:78-86.

Bußler, S., Steins, V., Ehlbeck, J., Schlüter, O.K. (2015). Impact of thermal treatment versus cold atmospheric plasma processing on the techno-functional protein properties from Pisum sativum 'Salamanca'. Journal of Food Engineering. 167:166-74. 


\section{ACCEPTED MANUSCRIPT}

Cannon, P. R. (1945). The importance of proteins in resistance to infection. Journal of the American Medical Association. 128: 360-362.

Chen, C.W., Lee, H.M. and Chang, M.B. (2008). Inactivation of aquatic microorganisms by lowfrequency AC discharges. IEEE Transactions on Plasma Science. 36:215-9.

Chen, H.H., Chang, H.C., Chen, Y.K., Hung, C.L., Lin, S.Y. and Chen, Y.S. (2016). An improved process for high nutrition of germinated brown rice production: Low-pressure plasma. Food chemistry. 191:120-7.

Chen, H.H., Hung, C.L., Lin, S.Y. and Liou, G.J. (2015). Effect of Low-Pressure Plasma Exposure on the Storage Characteristics of Brown Rice. Food and Bioprocess Technology. 8:471-7.

Conrads, H. and Schmidt, M. (2000). Plasma generation and plasma sources. Plasma Sources Science and Technology. 9:441.

Cui, H., Ma, C., Li, C. and Lin, L. (2016). Enhancing the antibacterial activity of thyme oil against Salmonella on eggshell by plasma-assisted process. Food Control. 70:183-90.

Cuq, B., Gontard, N., Cuq, J-L and Guilbert, S. (1997). Selected functional properties of fish myofibrillar protein-based films as affected by hydrophilic plasticizers. Journal of Agricultural and Food Chemistry. 45:622-6.

Dai, C., Wang, B. and Zhao, H. (2005). Microencapsulation peptide and protein drugs delivery system. Colloids and Surfaces B: Biointerfaces. 41(2):117-120.

Damodaran, S. (1994). Structure-function relationship of food proteins. Protein functionality in food systems. 10:1-37. 


\section{ACCEPTED MANUSCRIPT}

DeGeyter, N. and Morent, R. (2012). Nonthermal plasma sterilization of living and nonliving surfaces. Annual Review of Biomedical Engineering. 14:255-74.

Deng, X., Shi, J. and Kong, M.G. (2007). Protein destruction by a helium atmospheric pressure glow discharge: capability and mechanisms. Journal of Applied Physics. 101:074701.

Desmet, T., Morent, R., Geyter, N.D., Leys, C., Schacht, E. and Dubruel, P. (2009). Nonthermal plasma technology as a versatile strategy for polymeric biomaterials surface modification: a review. Biomacromolecules. 10:2351-78.

Deutsch, J.C., Santhosh-Kumar, C. and Kolhouse, J.F. (1999). Glutathione oxidation in real time by thermospray liquid chromatography--mass spectrometry. Journal of Chromatography A.862:161-8.

DeVos, P., Faas, M.M., Spasojevic, M. and Sikkema, J. (2010). Encapsulation for preservation of functionality and targeted delivery of bioactive food components. International Dairy Journal. 20(4): 292-302.

Doubla, A., Bello, L.B., Fotso, M. and Brisset, J-L. (2008). Plasmachemical decolourisation of Bromothymol Blue by gliding electric discharge at atmospheric pressure. Dyes and Pigments. $77: 118-24$

Ehlbeck, J., Schnabel, U., Polak, M., Winter, J., Von Woedtke, T. and Brandenburg, R. (2010). Low temperature atmospheric pressure plasma sources for microbial decontamination. Journal of Physics D: Applied Physics. 44:013002.

El-Aziz, M.F.A., Mahmoud, E.A. and Elaragi, G.M. (2014). Non thermal plasma for control of the Indian meal moth, Plodia interpunctella (Lepidoptera: Pyralidae). Journal of Stored Products Research. 59:215-21. 


\section{ACCEPTED MANUSCRIPT}

Eliasson, B. and Kogelschatz, U. (1991). Nonequilibrium volume plasma chemical processing. IEEE Transactions on Plasma Science. 19:1063-77.

Foegeding, E.A., Davis, J.P. (2011). Food protein functionality: A comprehensive approach. Food Hydrocolloids. 25:1853-64.

Fridman, A., Chirokov, A. and Gutsol, A. (2005). Non-thermal atmospheric pressure discharges. Journal of Physics D: Applied Physics. 38:R1.

Fridman, G., Gutsol, A., Shekhter, A.B., Vasilets, V.N. and Fridman, A. (2008). Applied plasma medicine. Plasma Processes and Polymers. 5:503-33.

Gaunt, L.F., Beggs, C.B. and Georghiou G.E. (2006). Bactericidal action of the reactive species produced by gas-discharge nonthermal plasma at atmospheric pressure: a review. IEEE Transactions on Plasma Science. 34:1257-69.

Gennadios, A., and Weller, C.L. (1990). Edible films and coatings from wheat and corn proteins. Food Technology. 44:63-69.

Ghaffari, A., Miller, C., McMullin, B. and Ghahary, A. (2006). Potential application of gaseous nitric oxide as a topical antimicrobial agent. Nitric oxide.14:21-9.

Gregório, J., Leroy, O., Leprince, P. Alves, L.L, and Boisse-Laporte, C. (2009). Design of a microwave microplasma source at atmospheric pressure. IEEE Transactions on Plasma Science. 37: 797-808.

Guillard,V., Mauricio-Iglesias, M., and Gontard, N. (2010). Effect of novel food processing methods on packaging: structure, composition, and migration properties.Critical Reviews in Food Science and Nutrition. 50:969--988. 


\section{ACCEPTED MANUSCRIPT}

Haque, M.A., Bsmrau, G., Timilsena, B.Y.P., Adhikari, B. (2016). Food Proteins, Structure, and Function. Reference Module in Food Science. 1-9.

Hasirci, N., Endogan, T., Vardar, E., Kiziltay, A. and Hasirci, V. (2010). Effect of oxygen plasma on surface properties and biocompatibility of PLGA films. Surface and Interface Analysis. 42:486-491.

He, B., Yang, Y., Yuen, M.F., Chen, X., Lee, C.S. and Zhang, W. (2013). Vertical nanostructure arrays by plasma etching for applications in biology, energy, and electronics. Nano Today.8:26589.

Hendrickx, M., Ludikhuyze, L., Van den Broeck, I. and Weemaes, C. (1998). Effects of high pressure on enzymes related to food quality. Trends in Food Science \& Technology. 5:197-203.

Henselová, M., Slováková, L., Martinka, M. and Zahoranová, A. (2012). Growth, anatomy and enzyme activity changes in maize roots induced by treatment of seeds with low-temperature plasma. Biologia. 67:490-7.

Hirose, M., Yasui, T. and Yotuyanagi, M. (1982). Surface processing apparatus utilizing microwave plasma. U.S. Patent 4,339,326.

Hoffmann, C., Berganza, C. and Zhang, J. (2013). Cold Atmospheric Plasma: methods of production and application in dentistry and oncology. Medical Gas Research. 3:1-21.

Houston, K., Weinkauf, D. and Stewart, F. (2002). Gas transport characteristics of plasma treated poly (dimethylsiloxane) and polyphosphazene membrane materials. Journal of Membrane Science. 205:103-12. 


\section{ACCEPTED MANUSCRIPT}

Huang, C-Y., Wu, J-Y., Tsai, C-S., Hsieh, K-H., Yeh, J-T.and Chen K-N. (2013). Effects of argon plasma treatment on the adhesion property of ultra high molecular weight polyethylene (UHMWPE) textile. Surface and Coatings Technology. 231:507-11.

Hughey, V. and Johnson, E. (1987). Antimicrobial activity of lysozyme against bacteria involved in food spoilage and food-borne disease. Applied and Environmental Microbiology. 53:2165-70. Huque, R., Wills, R., Pristijono, P. and Golding, J. (2013). Effect of nitric oxide (NO) and associated control treatments on the metabolism of fresh-cut apple slices in relation to development of surface browning. Postharvest Biology and Technology. 78:16-23.

Jurado, Á., García, C., Timón, M.L. and Carrapiso, A.I. (2007). Effect of ripening time and rearing system on amino acid-related flavour compounds of Iberian ham. Meat Science. 75(4):585-594.

Ke, Z., Huang, Q., Dang, B., Lu, Y., Yuan, H. and Zhang, S. (2010). A study of low-energy ion induced radiolysis of thiol-containing amino acid cysteine in the solid and aqueous solution states. Nuclear Instruments and Methods in Physics Research Section B: Beam Interactions with Materials and Atoms. 268:2729-34.

Ke, Z., Yu, Z. and Huang, Q. (2013). Assessment of damage of glutathione by glow discharge plasma at the gas--solution interface through Raman spectroscopy. Plasma Processes and Polymers. 10:181-8.

Khan, K. and Elia, M. (1991). Factors affecting the stability of L-glutamine in solution. Clinical Nutrition. 10:186-92.

Kim, J-H., Lee, M-A., Han, G-J. and Cho, B-H. (2014). Plasma in dentistry: a review of basic concepts and applications in dentistry. Acta Odontologica Scandinavica. 72:1-12. 


\section{ACCEPTED MANUSCRIPT}

Kim, M.S., Kim, N., Kim, S.E., Jo, H.J., Shin, C.M. and Lee, S.H. (2013). Long-term Follow-up Helicobacter Pylori Reinfection Rate and Its Associated Factors in Korea. Helicobacter. 18:13542.

Klämpfl, T.G., Isbary, G., Shimizu, T., Li, Y-F., Zimmermann, J.L. and Stolz, W. (2012). Cold atmospheric air plasma sterilization against spores and other microorganisms of clinical interest. Applied and Environmental Microbiology. 78:5077-82.

Knorr, D., Froehling, A., Jaeger, H., Reineke, K., Schlueter, O. and Schoessler, K. (2011). Emerging technologies in food processing. Annual Review of Food Science and Technology. 2:203-35.

Kogelschatz, U. (2003). Dielectric-barrier discharges: their history, discharge physics, and industrial applications. Plasma Chemistry and Plasma Processing. 23:1-46.

Kossyi, I. A., Kostinsky, A. Y., Matveyev, A. A., and Silakov, V. P. (1992). Kinetic scheme of the non-equilibrium discharge in nitrogen-oxygen mixtures. Plasma Sources Science and Technology. 1:207.

Kuo, Y-H., Rozan, P., Lambein, F., Frias, J., Vidal-Valverde, C. (2004). Effects of different germination conditions on the contents of free protein and non-protein amino acids of commercial legumes. Food chemistry. 86:537-45.

Kusano, Y. (2009). Plasma surface modification at atmospheric pressure. Surface Engineering. 25(6): 415--416.

Lackmann, J-W., Schneider, S., Edengeiser, E., Jarzina, F., Brinckmann, S. and Steinborn, E. (2013). Photons and particles emitted from cold atmospheric-pressure plasma inactivate bacteria 


\section{ACCEPTED MANUSCRIPT}

and biomolecules independently and synergistically. Journal of The Royal Society Interface. 10:20130591.

Lackmann, J., Baldus, S., Steinborn, E., Edengeiser, E., Kogelheide, F. andLangklotz, S. (2015).

A dielectric barrier discharge terminally inactivates RNase A by oxidizing sulfur-containing amino acids and breaking structural disulfide bonds. Journal of Physics D: Applied Physics. 48:494003.

Laroussi, M. (2014). From killing bacteria to destroying cancer cells: 20 years of plasma medicine. Plasma Processes and Polymers. 11:1138-41.

Laroussi, M. and Akan, T. (2007). Arc-Free Atmospheric Pressure Cold Plasma Jets: A Review. Plasma Processes and Polymers. 4:777-88.

Lee, K., Paek, K-h., Ju, W. and Lee, Y. (2006). Sterilization of bacteria, yeast, and bacterial endospores by atmospheric-pressure cold plasma using helium and oxygen. Journal of Microbiology-Seoul. 44:269-75.

Lee, K.H., Kim, H-J., Woo, K.S., Jo, C., Kim, J-K. and Kim, S.H. (2016). Evaluation of cold plasma treatments for improved microbial and physicochemical qualities of brown rice. LWTFood Science and Technology. 73:442-7.

Lerouge, S. and Wertheimer, M. (2001). Plasma sterilization: a review of parameters, mechanisms, and limitations. Plasmas and Polymers.6:175-88.

Li, H.P., Wang, L.Y., Li, G., Jin, L.H., Le, P.S. and Zhao, H.X. (2011). Manipulation of Lipase Activity by the Helium Radio Frequency, Atmospheric Pressure Glow Discharge Plasma Jet. Plasma Processes and Polymers. 8:224-9. 


\section{ACCEPTED MANUSCRIPT}

Li, M-w., Xu, G-h., Tian, Y-l., Chen, L. and Fu, H-f. (2004). Carbon dioxide reforming of methane using DC corona discharge plasma reaction. The Journal of Physical Chemistry A. 108:1687-93.

Liu, C., Cui, N., Brown, N.M. and Meenan, B.J. (2004). Effects of DBD plasma operating parameters on the polymer surface modification. Surface and Coatings Technology. 185:311-20. Malshe, P., Mazloumpour, M., El-Shafei, A. and Hauser, P. (2013). Multi-functional military textile: Plasma-induced graft polymerization of a C6 fluorocarbon for repellent treatment on nylon--cotton blend fabric. Surface and Coatings Technology. 217:112-8.

Marouf-Khelifa, K., Abdelmalek, F., Khelifa, A., Belhadj, M., Addou, A. and Brisset, J-L. (2006). Reduction of nitrite by sulfamic acid and sodium azide from aqueous solutions treated by gliding arc discharge. Separation and Purification Technology. 50:373-9.

McClements, D.J. (2006). Non-covalent interactions between proteins and polysaccharides. Biotechnology Advances. 24:621-5.

McClements, D.J., Decker, E.A., Park, Y. and Weiss, J. (2009). Structural design principles for delivery of bioactive components in nutraceuticals and functional foods. Critical reviews in food science and nutrition. 49(6):577-606.

Meinlschmidt, P., Ueberham, E., Lehmann, J., Reineke, K., Schlüter, O. and Schweiggert-Weisz, U. (2016). The effects of pulsed ultraviolet light, cold atmospheric pressure plasma, and gammairradiation on the immunoreactivity of soy protein isolate. Innovative Food Science \& Emerging Technologies. 38:374-383.

Misra, N.N., Kaur, S., Tiwari, B.K., Kaur, A., Singh, N. and Cullen, P. (2015). Atmospheric pressure cold plasma (ACP) treatment of wheat flour. Food Hydrocolloids. 44:115-21. 


\section{ACCEPTED MANUSCRIPT}

Misra, N.N., Marynenko, A., Chemat, F., Paniwnyk, L., Barba, J.F. and Jambrak, R.A. (2017). Thermodynamics, trasport phenomena and electrochemistry of external field assisted nonthermal food technologies. Critical Reviews in Food Science and Nutrition, DOI: 10.1080/10408398.2017.1287660.

Misra, N.N., Pankaj, S.K., Segat, A. and Ishikawa, K. (2016). Cold plasma ineraction with enzymes in food and model systems. Trends in Food Science and Technology. Doi: 10.1016/j.tifs. 2016.07.0011.

Mitragotri, S., Burke, P.A. and Langer, R. (2014). Overcoming the challenges in administering biopharmaceuticals: formulation and delivery strategies. Nature reviews Drug discovery. 13(9):655-672.

Moisan, M., Barbeau, J., Crevier, M-C., Pelletier, J., Philip, N. andSaoudi, B. (2002). Plasma sterilization. Methods and mechanisms. Pure and Applied Chemistry. 74:349-58.

Moisan, M., Barbeau, J., Moreau, S., Pelletier, J., Tabrizian, M. and Yahia, L.H. (2001). Lowtemperature sterilization using gas plasmas: a review of the experiments and an analysis of the inactivation mechanisms. International Journal of Pharmaceutics. 226:1-21.

Moreau, M., Orange, N. and Feuilloley, M. (2008). Non-thermal plasma technologies: new tools for bio-decontamination. Biotechnology Advances. 26:610-7.

Morent, R., De Geyter, N., Desmet, T., Dubruel, P. and Leys, C. (2011). Plasma surface modification of biodegradable polymers: a review. Plasma Processes and Polymers. 8:171-90.

Motrescu, I., Ogino, A., Tanaka, S., Fujiwara, T., Kodani, S. and Kawagishi, H. (2011). Mechanism of peptide modification by low-temperature microwave plasma. Soft Matter. 7:484550. 


\section{ACCEPTED MANUSCRIPT}

Niemira, B.A. (2012). Cold plasma decontamination of foods. Annual Review of Food Science and Technology. 3:125-42.

Nooji, J. (2011). Reduction of wheat allergen potency by pulsed ultraviolet light, high hydrostatic pressure and nonthermal plasma. Gainesville, Florida: University of Florida.

Oh, J-S., Aranda-Gonzalvo, Y. and Bradley, J.W. (2011). Time-resolved mass spectroscopic studies of an atmospheric-pressure helium microplasma jet. Journal of Physics D: Applied Physics. 44:365202.

Oh, Y.A., Roh, S.H. and Min, S.C. (2016). Cold plasma treatments for improvement of the applicability of defatted soybean meal-based edible film in food packaging. Food Hydrocolloids. $58: 150-9$.

Pankaj, S., Misra, N.N. and Cullen, P. (2013). Kinetics of tomato peroxidase inactivation by atmospheric pressure cold plasma based on dielectric barrier discharge. Innovative Food Science \& Emerging Technologies. 19:153-7.

Pankaj, S.K., Bueno-Ferrer, C., Misra, N.N., Milosavljević, V., O|Donnell, C. and Bourke, P. (2014a). Applications of cold plasma technology in food packaging. Trends in Food Science \& Technology. 35:5-17.

Pankaj, S.K., Bueno-Ferrer, C., Misra, N.N., ONeill, L., Tiwari, B. and Bourke, P. (2014b). Physicochemical characterization of plasma-treated sodium caseinate film. Food Research International. 66:438-44.

Pankaj, S.K., Bueno-Ferrer, C., Misra, N.N., Bourke, P., Cullen, P. (2014C). Zein film: Effects of dielectric barrier discharge atmospheric cold plasma. Journal of Applied Polymer Science. 131 (18). 


\section{ACCEPTED MANUSCRIPT}

Perez-gago, M. and Krochta, J. (2001). Denaturation time and temperature effects on solubility, tensile properties, and oxygen permeability of whey protein edible films. Journal of Food Science. 66:705-10.

Perni, S., Shama, G., Hobman, J., Lund, P., Kershaw, C. and Hidalgo-Arroyo, G. (2007). Probing bactericidal mechanisms induced by cold atmospheric plasmas with Escherichia coli mutants. Applied Physics Letters. 90:073902.

Pinela, J. and Ferreira, C.F.R. I. (2015). Non-thermal Physical Technologies to Decontaminate and Extend the Shelf-life of Fruits and Vegetables: Trends Aiming at Quality and Safety. Critical Reviews in Food Science and Nutrition. DOI: 10.1080/10408398.2015.1046547.

Pröfrock, D. and Prange, A. (2012). Inductively Coupled Plasma--Mass Spectrometry (ICP-MS) for quantitative analysis in environmental and life sciences: a review of challenges, solutions, and trends. Applied Spectroscopy. 66:843-68.

Puač, N., Živković, S., Selaković, N., Milutinović, M., Boljević, J. and Malović, G. (2014). Long and short term effects of plasma treatment on meristematic plant cells. Applied Physics Letters. 104:214106.

Ramazzina, I., Berardinelli, A., Rizzi, F., Tappi, S., Ragni, L. and Sacchetti, G. (2015). Effect of cold plasma treatment on physico-chemical parameters and antioxidant activity of minimally processed kiwifruit. Postharvest Biology and Technology. 107:55-65.

Ressouany, M., Vachon, C. and Lacroix, M. (1998). Irradiation dose and calcium effect on the mechanical properties of cross-linked caseinate films. Journal of Agricultural and Food Chemistry. 46:1618-23. 


\section{ACCEPTED MANUSCRIPT}

Roller, S. (1995). The quest for natural antimicrobials as novel means of food preservation: status report on a European research project. International biodeterioration \& biodegradation. 36:333-45.

Roth, J.R., Rahel, J., Dai, X. and Sherman, D.M. (2005). The physics and phenomenology of One Atmosphere Uniform Glow Discharge Plasma (OAUGDP ${ }^{\mathrm{TM}}$ ) reactors for surface treatment applications. Journal of Physics D: Applied Physics. 38:555.

Rumbach, P., Witzke, M., Sankaran, R.M. and Go, D.B. (2013). Decoupling interfacial reactions between plasmas and liquids: charge transfer vs plasma neutral reactions. Journal of the American Chemical Society. 135:16264-7.

Schlüter, O., Ehlbeck, J., Hertel, C., Habermeyer, M., Roth, A. and Engel, K.H. (2013). Opinion on the use of plasma processes for treatment of foods. Molecular Nutrition \& Food Research. 57:920-7.

Segat, A., Misra, N.N., Cullen, P., andInnocente, N. (2015). Atmospheric pressure cold plasma (ACP) treatment of whey protein isolate model solution. Innovative Food Science \& Emerging Technologies. 29:247-54.

Segat, A., Misra, N.N., Cullen, P. and Innocente, N. (2016). Effect of atmospheric pressure cold plasma (ACP) on activity and structure of alkaline phosphatase. Food and Bioproducts Processing. 98:181-8.

Shriver, S.K. (2011). Effect of selected emerging nonthermal processingmethods on the allergen reactivity of Atlantic white shrimp (Litopenaeus setiferus). FL, USA:, 32611. Gainesville, Florida: University of Florida. 


\section{ACCEPTED MANUSCRIPT}

Shriver, S.K. and Yang, W.W. (2011). Thermal and nonthermal methods for food allergen control. Food Engineering Reviews. 3:26-43.

Sparavigna, A. (2008). Plasma treatment advantages for textiles. http://arxiv.org/ abs/0801.3727

Soloshenko, I.A., Tsiolko, V.V., Khomich, V.A., Shchedrin, A.I., Ryabtsev, A.V., Bazhenov, V.Y. and Mikhno, I.L. (2000). Sterilization of medical productsin low-pressure glow discharges. Plasma Physics Reports. 26 (9):792-800.

Stoffels, E., Flikweert, A., Stoffels, W. andKroesen, G. (2002). Plasma needle: a non-destructive atmospheric plasma source for fine surface treatment of (bio) materials. Plasma Sources Science and Technology. 11:383.

Stutz, H., Illers, K.H., Mertes, J. (1990). A generalized theory for the glass transition temperature of crosslinked and uncrosslinked polymers. Journal of Polymer Science Part B: Polymer Physics. 28:1483-98.

Surowsky, B., Fischer, A., Schlueter, O. and Knorr, D. (2013). Cold plasma effects on enzyme activity in a model food system. Innovative Food Science \& Emerging Technologies. 19:146-52. Surowsky, B., Fröhling, A., Gottschalk, N., Schlüter, O. and Knorr, D. (2014). Impact of cold plasma on Citrobacter freundii in apple juice: Inactivation kinetics and mechanisms. International Journal of Food Microbiology. 174:63-71.

Surowsky, B., Schlüter, O. and Knorr, D. (2015). Interactions of non-thermal atmospheric pressure plasma with solid and liquid food systems: a review. Food Engineering Reviews. 7:82108. 


\section{ACCEPTED MANUSCRIPT}

Takai, E., Kitamura, T., Kuwabara, J., Ikawa, S., Yoshizawa, S. and Shiraki, K., Kawasaki, H., Ryuichi, A., and Katsuhisa, K. (2014). Chemical modification of amino acids by atmosphericpressure cold plasma in aqueous solution. Journal of Physics D: Applied Physics. 47:285403.

Takai, E., Kitano, K., Kuwabara, J. and Shiraki, K. (2012). Protein Inactivation by Lowtemperature Atmospheric Pressure Plasma in Aqueous Solution. Plasma Processes and Polymers. 9:77-82.

Tammineedi, C.V., Choudhary, R., Perez-Alvarado, G.C. and Watson, D.G. (2013). Determining the effect of UV-C, high intensity ultrasound and nonthermal atmospheric plasma treatments on reducing the allergenicity of $\alpha$-casein and whey proteins. LWT.Food Science and Technology. 54:35-41.

Tappi, S., Berardinelli, A., Ragni, L., Dalla Rosa, M., Guarnieri, A. and Rocculi, P. (2014). Atmospheric gas plasma treatment of fresh-cut apples. Innovative Food Science \& Emerging Technologies. 21:114-22.

Tavares, G.M., Croguennec, T., Carvalho, A.F. and Bouhallab, S. (2014). Milk proteins as encapsulation devices and delivery vehicles: applications and trends. Trends in Food Science \& Technology. 37(1): 5-20.

Tresp, H., Hammer, M.U., Winter, J., Weltmann, K. and Reuter, S. (2013). Quantitative detection of plasma-generated radicals in liquids by electron paramagnetic resonance spectroscopy. Journal of Physics D: Applied Physics. 46:435401.

Weltmann, K.D., Polak, M., Masur, K., Von Woedtke, T., Winter, J. and Reuter, S. (2012). Plasma processes and plasma sources in medicine. Contributions to Plasma Physics. 52:644-54. 


\section{ACCEPTED MANUSCRIPT}

Wihodo, M. and Moraru, C.I. (2013). Physical and chemical methods used to enhance the structure and mechanical properties of protein films: A review. Journal of Food Engineering. 114:292-302.

Winter, J., Brandenburg, R. and Weltmann, K-D. (2015). Atmospheric pressure plasma jets: an overview of devices and new directions. Plasma Sources Science and Technology. 24:064001.

Wu, G., Wu, Z., Dai, Z., Yang, Y., Wang, W., Liu, C., Wang, B., Wang, J. and Yin, Y. (2013). Dietary requirements of "nutritionally non-essential amino acids" by animals and humans. Amino Acids. 44(4):1107-1113.

Yong, H. I., Kim, H.-J., Park, S., Kim, K., Choe, W., Yoo, S. J., and Jo, C. (2015). Pathogen inactivationand quality changes in sliced cheddar cheese treated using exible thin-layer dielectric barrier discharge plasma. Food Research International, 69:57-63.

Zaks, A. and Klibanov, A.M. (1984). Enzymatic catalysis in organic media at 100 degrees C. Science. 224:1249-51.

Zhang, H. and Mittal, G. (2010). Biodegradable protein-based films from plant resources: A review. Environmental Progress \& Sustainable Energy. 29:203-20.

Zhang, H., Xu, Z., Shen, J., Li, X., Ding, L. andMa, J.(2015). Effects and Mechanism of atmospheric-pressure dielectric barrier discharge cold plasma on lactate dehydrogenase (LDH) enzyme. Scientific Reports. 5:10031.

Zhu, K-X., Lian, C-X., Guo, X-N., Peng, W. and Zhou, H-M. (2011). Antioxidant activities and total phenolic contents of various extracts from defatted wheat germ. Food Chemistry. 126:11226. 


\section{ACCEPTED MANUSCRIPT}

Zhu, W., Lee, S.J., Castro, N.J., Yan, D., Keidar, M. and Zhang, L.G. (2016). Synergistic Effect of cold atmospheric plasma and drug loaded core-shell nanoparticles on inhibiting breast cancer cell growth. Scientific reports. 6.

Ziuzina, D., Patil, S., Cullen, P., Keener, K. and Bourke, P. (2013). Atmospheric cold plasma inactivation of Escherichia coli in liquid media inside a sealed package. Journal of Applied Microbiology. 114:778-87. 


\section{ACCEPTED MANUSCRIPT}

Table 1: Results of cold plasma influence on physical and mechanical properties of protein based films

\begin{tabular}{|c|c|c|c|c|c|c|c|}
\hline \multirow{2}{*}{$\begin{array}{l}\text { Food component/ } \\
\text { property }\end{array}$} & \multirow[t]{2}{*}{ Matrix } & \multirow[t]{2}{*}{ Plasma Source } & \multicolumn{3}{|c|}{ Treatment Conditions } & \multirow[t]{2}{*}{ Results } & \multirow[t]{2}{*}{ References } \\
\hline & & & Gas type & Max time & $\begin{array}{l}\text { Mode of } \\
\text { exposure }\end{array}$ & & \\
\hline Defatted soybean meal & DSM/ glycerol & $\begin{array}{l}\text { Low pressure } \\
\text { microwave } \\
\text { powered }\end{array}$ & $\begin{array}{l}\mathrm{O}_{2}, \mathrm{~N}_{2}, \mathrm{Air}, \mathrm{He}, \\
\operatorname{Ar}(1 \mathrm{std} \mathrm{L} / \mathrm{min})\end{array}$ & $25 \mathrm{~min}$ & Direct & $\begin{array}{l}\text {-Increase in } \\
\text { polymer surface } \\
\text { roughness }\end{array}$ & (Oh, Roh, 2016) \\
\hline \multirow[t]{3}{*}{ (DSM) -based film } & & $\begin{array}{l}\text { cold Plasma ( } 2.45 \\
\mathrm{GHz}, 650 \mathrm{~W})\end{array}$ & & & & $\begin{array}{l}\text {-Increase in ink } \\
\text { adhesion by } \mathrm{O} 2 \\
\text { and air plasma } \\
\text { gas }\end{array}$ & \\
\hline & & & & & & $\begin{array}{l}\text {-Increase in the } \\
\text { film elongation } \\
\text { by using } \mathrm{O}_{2}, \mathrm{~N}_{2} \text {, } \\
\mathrm{He} \text {, and } \mathrm{Ar} \text { as } \\
\text { plasma gas }\end{array}$ & \\
\hline & & & & & & $\begin{array}{l}\text {-Increase in film } \\
\text { lightness by } \\
\text { using } \mathrm{N}_{2} \text { and } \mathrm{Ar} \\
\text { by using plasma } \\
\text { gas. }\end{array}$ & \\
\hline \multirow[t]{3}{*}{ Zein film } & $\begin{array}{l}\text { Zein/ ethanol/ } \\
\text { glycerol }\end{array}$ & DBD & Air (48\% RH) & $5 \min$ & Direct & $\begin{array}{l}\text {-Increased the } \\
\text { surface } \\
\text { roughness and } \\
\text { equillibrium } \\
\text { moisture content } \\
\text { of the }\end{array}$ & $\begin{array}{l}\text { (Pankaj, Bueno-Ferrer, } \\
\text { 2014c) }\end{array}$ \\
\hline & & $(80 \mathrm{kV}, 50 \mathrm{~Hz})$ & & & & $\begin{array}{l}\text { Zein film in a } \\
\text { direct } \\
\text { relationship with } \\
\text { the applied } \\
\text { voltage level. }\end{array}$ & \\
\hline & & & & & & $\begin{array}{l}\text {-No significant } \\
\text { difference in the } \\
\text { thermal stability }\end{array}$ & \\
\hline \multirow[t]{2}{*}{ Sodium caseinate film } & $\begin{array}{l}\text { Glyce rol/ } \\
\text { sodium } \\
\text { caseinate }\end{array}$ & DBD & Air & $5 \min$ & Direct & $\begin{array}{l}\text {-Increase in the } \\
\text { surface } \\
\text { roughness }\end{array}$ & $\begin{array}{l}\text { (Pankaj, Bueno-Ferrer, } \\
\text { 2014b) }\end{array}$ \\
\hline & & $(70 \mathrm{kV}, 50 \mathrm{~Hz})$ & $(53 \% \mathrm{RH})$ & & & $\begin{array}{l}\text {-Increase in the } \\
\text { hydrophilicity }\end{array}$ & \\
\hline
\end{tabular}

DBD-Dielectric barrier discharge 


\section{ACCEPTED MANUSCRIPT}

Table 2: Recent studies on the influence of plasma treatment on the techno-functional properties of proteins

\begin{tabular}{|c|c|c|c|c|c|c|c|}
\hline \multirow{2}{*}{$\begin{array}{l}\text { Food component/ } \\
\text { property }\end{array}$} & \multirow[t]{2}{*}{ Matrix } & \multirow[t]{2}{*}{ Plasma Source } & \multicolumn{3}{|c|}{ Treatment Conditions } & \multirow[t]{2}{*}{ Results } & \multirow[t]{2}{*}{ References } \\
\hline & & & Gas type & Max time & $\begin{array}{l}\text { Mode of } \\
\text { exposure }\end{array}$ & & \\
\hline$\alpha$-casein & \multirow{3}{*}{$\begin{array}{l}\text { Sodium } \\
\text { phosphate } \\
\text { buffered saline } \\
(\mathrm{pH} \mathrm{7.4)}\end{array}$} & \multirow[t]{3}{*}{$\begin{array}{l}\text { Plasma jet (13.56 } \\
\mathrm{MHz})\end{array}$} & \multirow[t]{3}{*}{$\operatorname{Ar}(30.71 / \mathrm{min})$} & \multirow[t]{3}{*}{$15 \mathrm{~min}$} & \multirow[t]{3}{*}{ Indirect } & $\begin{array}{l}\text {-No changes in } \\
\text { allergenicity }\end{array}$ & \multirow[t]{3}{*}{$\begin{array}{l}\text { (Tammineedi, } \\
\text { Choudhary, 2013) }\end{array}$} \\
\hline \multirow[t]{2}{*}{$\begin{array}{l}\text { Whey protein ( } \beta- \\
\text { lactoglobulin and } \alpha- \\
\text { lactalbumin) }\end{array}$} & & & & & & $\begin{array}{l}\text {-No noticeable } \\
\text { change in gel } \\
\text { band intensities } \\
\text { and protein } \\
\text { concentration } \\
\text { (DS-PAGE } \\
\text { results) }\end{array}$ & \\
\hline & & & & & & $\begin{array}{l}\text {-No significant } \\
\text { difference in IgE } \\
\text { binding values } \\
\text { (Ci-ELISA } \\
\text { analysis) }\end{array}$ & \\
\hline \multirow{4}{*}{$\begin{array}{l}\text { Whey protein } \\
\text { isolate (including } \beta \text { - } \\
\text { lactoglobulin, } \alpha- \\
\text { lactoalbumin, and } \\
\text { bovine serum } \\
\text { albumin) }\end{array}$} & \multirow[t]{4}{*}{$\begin{array}{l}\text { Phosphate } \\
\text { buffer (pH 6.8) }\end{array}$} & \multirow[t]{4}{*}{$\begin{array}{l}\text { DBD (70 kV, } \\
\text { discharge gap } 44 \\
\mathrm{~mm})\end{array}$} & \multirow[t]{4}{*}{ Air } & \multirow[t]{4}{*}{$60 \mathrm{~min}$} & \multirow[t]{4}{*}{ Direct } & $\begin{array}{l}\text {-Increase in } \\
\text { yellow colour }\end{array}$ & \multirow[t]{4}{*}{ (Segat, Misra, 2015) } \\
\hline & & & & & & -Decrease in $\mathrm{pH}$ & \\
\hline & & & & & & $\begin{array}{l}\text {-Mild oxidation } \\
\text { in the proteins }\end{array}$ & \\
\hline & & & & & & $\begin{array}{l}\text {-Improvement in } \\
\text { foaming and } \\
\text { emulsifying } \\
\text { capacity }\end{array}$ & \\
\hline Wheat flour & - & $\begin{array}{l}\text { Plasma discharge } \\
\text { by DC power } \\
\text { supply }(20 \mathrm{~V}, 9 \\
\mathrm{kHz})\end{array}$ & Air & $120 \mathrm{~s}$ & Direct & $\begin{array}{l}\text {-Stronger dough } \\
\text { (Reomixer) }\end{array}$ & (Bahrami, Bayliss, 2016) \\
\hline \multirow{2}{*}{$\begin{array}{l}\text { Hard and soft wheat } \\
\text { flour }\end{array}$} & \multirow[t]{2}{*}{-} & DBD & \multirow{2}{*}{$\begin{array}{l}\text { Air }(45 \pm 1 \% \\
\text { relative } \\
\text { humidity) }\end{array}$} & \multirow[t]{2}{*}{$10 \mathrm{~min}$} & \multirow[t]{2}{*}{ Direct } & \multirow{2}{*}{$\begin{array}{l}\text {-Improvement in } \\
\text { the dough } \\
\text { strength and } \\
\text { optimum mixing } \\
\text { time }\end{array}$} & \multirow[t]{2}{*}{ (Misra, Kaur, 2015) } \\
\hline & & $(50 \mathrm{~Hz}, 70 \mathrm{kV})$ & & & & & \\
\hline \multirow[t]{2}{*}{$\begin{array}{l}\text { Pea protein } \\
\text { isolates(crude } \\
\text { protein content } \\
81.2 \%)\end{array}$} & \multirow[t]{2}{*}{$\begin{array}{l}\text { Freeze dried } \\
\text { and grinded } \\
\text { pea protein } \\
\text { isolate powder }\end{array}$} & $\begin{array}{l}\text { DBD (8.8 kVPP, } \\
3.0 \mathrm{kHz})\end{array}$ & \multirow[t]{2}{*}{ Air } & \multirow[t]{2}{*}{$10 \mathrm{~min}$} & \multirow[t]{2}{*}{ Semi-direct } & $\begin{array}{l}\text {-Increase in } \\
\text { water and fat } \\
\text { binding }\end{array}$ & \multirow[t]{2}{*}{ (Bußler, Steins, 2015) } \\
\hline & & & & & & $\begin{array}{l}\text {-Increase in the } \\
\text { protein solubility }\end{array}$ & \\
\hline
\end{tabular}




\section{ACCEPTED MANUSCRIPT}

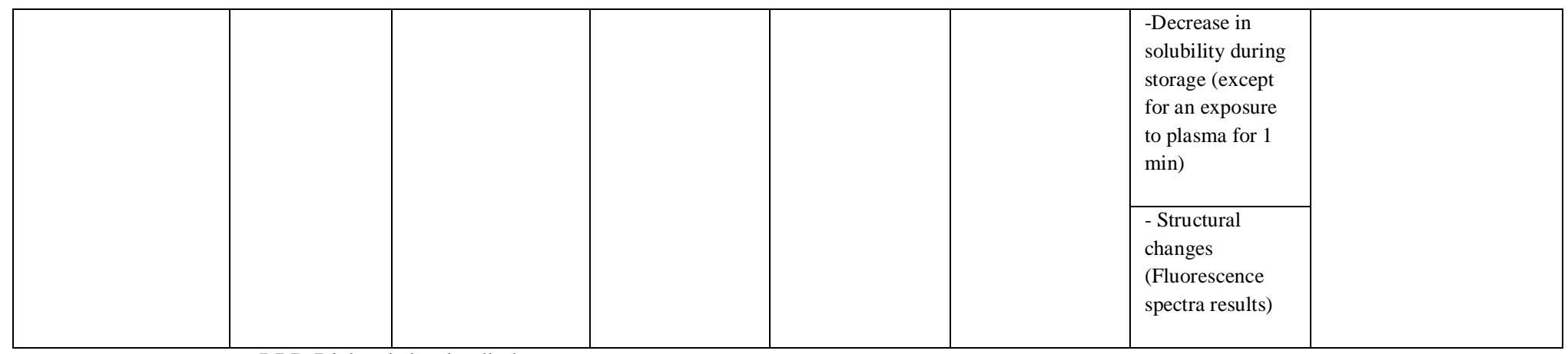

DBD-Dielectric barrier discharge 


\section{ACCEPTED MANUSCRIPT}

Table 3. Recent findings of changes in the enzyme activity following plasma exposure

\begin{tabular}{|c|c|c|c|c|c|c|c|}
\hline \multirow{2}{*}{$\begin{array}{l}\text { Food component/ } \\
\text { property }\end{array}$} & \multirow[t]{2}{*}{ Matrix } & \multirow[t]{2}{*}{ Plasma Source } & \multicolumn{3}{|l|}{ Treatment Conditions } & \multirow[t]{2}{*}{ Results } & \multirow[t]{2}{*}{ Reference } \\
\hline & & & Gas type & Max time & $\begin{array}{l}\text { Mode of } \\
\text { exposure }\end{array}$ & & \\
\hline Peroxidase & $\begin{array}{l}\text { Peroxidase } \\
\text { extract from } \\
\text { tomatoes }\end{array}$ & $\begin{array}{l}\text { DBD }(50 \mathrm{kV}, \\
\text { electrode gap } 26 \\
\mathrm{~mm})\end{array}$ & $\begin{array}{l}\text { Air ( } 42 \% \text { relative } \\
\text { humidity) }\end{array}$ & $5 \mathrm{~min}$ & Direct & $\begin{array}{l}\text {-Decrease in } \\
\text { activity } \\
\text {-Sigmoidal } \\
\text { logistic } \\
\text { inactivation } \\
\text { kinetics }\end{array}$ & (Pankaj, Misra, 2013) \\
\hline -Peroxidase & \multirow{3}{*}{$\begin{array}{l}\text { Two-layer } \\
\text { model food } \\
\text { system (base } \\
\text { on gellan gum) }\end{array}$} & \multirow{3}{*}{$\begin{array}{l}\text { Plasma jet (HF,1.1 } \\
\mathrm{MHz}, 65 \mathrm{~V})\end{array}$} & \multirow{3}{*}{$\begin{array}{l}\text { Ar } 0.05 \% \text { (0.01and } \\
0.1 \% \mathrm{O} 2)\end{array}$} & \multirow[t]{3}{*}{$6 \mathrm{~min}$} & \multirow[t]{3}{*}{ Direct } & -Decrease in both & \multirow[t]{3}{*}{ (Surowsky, Fischer, 2013) } \\
\hline \multirow[t]{2}{*}{$\begin{array}{l}\text {-Polyphenol } \\
\text { oxidase }\end{array}$} & & & & & & $\begin{array}{l}\text {-Polyphenol } \\
\text { oxidase was } \\
\text { more stable }\end{array}$ & \\
\hline & & & & & & $\begin{array}{l}-0.1 \% \text { oxygen } \\
\text { was the most } \\
\text { suitable gas } \\
\text { composition }\end{array}$ & \\
\hline $\begin{array}{l}\text {-Superoxide } \\
\text { dismutase }\end{array}$ & \multirow{5}{*}{$\begin{array}{l}\text { Maize roots } \\
\text { (after treating } \\
\text { seeds) }\end{array}$} & Diffuse Coplanar & \multirow[t]{5}{*}{ Ambient air } & \multirow[t]{5}{*}{$2 \mathrm{~min}$} & \multirow[t]{5}{*}{ Direct } & $\begin{array}{l}\text { In the 3-day-old } \\
\text { roots: }\end{array}$ & \multirow[t]{5}{*}{ (Henselová et al., 2012) } \\
\hline $\begin{array}{l}\text {-Uaiacol- } \\
\text { peroxidase }\end{array}$ & & DBD & & & & $\begin{array}{l}\text {-A slight, } \\
\text { significant } \\
\text { increase in } \\
\text { superoxide } \\
\text { dismutase } \\
\text { activity }\end{array}$ & \\
\hline -Catalase & & $(14 \mathrm{kHz})$ & & & & $\begin{array}{l}\text {-Decrease in } \\
\text { Catalase activity }\end{array}$ & \\
\hline \multirow[t]{2}{*}{-Dehydrogenase } & & & & & & $\begin{array}{l}\text {-Decrease in } \\
\text { uaiacol- } \\
\text { peroxidase } \\
\text { activity }\end{array}$ & \\
\hline & & & & & & $\begin{array}{l}\text {-Decrease in } \\
\text { Dehydrogenase } \\
\text { activity with the } \\
\text { time of } \\
\text { treatment. }\end{array}$ & \\
\hline - $\alpha$-amylase & Brown rice & $\begin{array}{l}\text { Low pressure plasma } \\
\text { system (DC high- } \\
\text { voltage supply, } 3 \\
\mathrm{kV} \text { ) }\end{array}$ & Air & $30 \mathrm{~min}$ & Direct & $\begin{array}{l}\text {-Decrease in } \alpha \text { - } \\
\text { amylase activity } \\
\text { in early storage } \\
\text { period }\end{array}$ & (Chen et al., 2015) \\
\hline
\end{tabular}




\section{ACCEPTED MANUSCRIPT}

\begin{tabular}{|c|c|c|c|c|c|c|c|}
\hline \multirow[t]{2}{*}{-Lipoxygenase } & & & & & & $\begin{array}{l}\text {-Decrease in } \\
\text { lipoxygenase } \\
\text { activity in } \\
\text { storage period }\end{array}$ & \\
\hline & & & & & & $\begin{array}{l}\text {-Significant } \\
\text { decrease in } \\
\text { lipoxygenase } \\
\text { activity by } \\
\text { increasing } \\
\text { thevoltageof } \\
\text { plasma }\end{array}$ & \\
\hline -Catalase & \multirow[t]{5}{*}{$\begin{array}{l}\text { Plodiainterpun } \\
\text { ctella }\end{array}$} & \multirow[t]{5}{*}{$\begin{array}{l}\text { Plasma jet }(20 \mathrm{kV} \text {, } \\
\text { gap between } \\
\text { electrodes of } 2-3 \\
\mathrm{~mm})\end{array}$} & \multirow[t]{5}{*}{ Air } & \multirow[t]{5}{*}{$\begin{array}{l}\text { Base on } \\
\text { pulses }(1,5, \\
10,15 \text { or } 20 \\
\text { pulses) }\end{array}$} & \multirow[t]{5}{*}{ Direct } & $\begin{array}{l}\text {-Plasma causes } \\
\text { oxidative damage } \\
\text { in } P \text {. } \\
\text { interpunctella } \\
\text { larvae }\end{array}$ & \multirow[t]{5}{*}{ (El-Aziz, Mahmoud, 2014) } \\
\hline $\begin{array}{l}\text {-Glutathione S- } \\
\text { transferase }\end{array}$ & & & & & & $\begin{array}{l}\text {-Increase in } \\
\text { catalase and } \\
\text { glutathione S- } \\
\text { transferase } \\
\text { activities. }\end{array}$ & \\
\hline \multirow[t]{3}{*}{-Lipid peroxidase } & & & & & & $\begin{array}{l}\text {-No significant } \\
\text { changes in lipid } \\
\text { peroxidase } \\
\text { activity }\end{array}$ & \\
\hline & & & & & & $\begin{array}{l}\text {-Increases in } \\
\text { mortality with } \\
\text { increase of } \\
\text { plasma pulses }\end{array}$ & \\
\hline & & & & & & $\begin{array}{l}\text {-Increases in } \\
\text { mortality with } \\
\text { increase of } \\
\text { distance from the } \\
\text { nozzle }\end{array}$ & \\
\hline \multirow[t]{3}{*}{$\begin{array}{l}\text { Lactate } \\
\text { dehydrogenase }\end{array}$} & \multirow[t]{3}{*}{$\begin{array}{l}\text { Phosphate } \\
\text { buffer solution } \\
\text { (PBS, pH: 7.5) }\end{array}$} & \multirow[t]{3}{*}{$\begin{array}{l}\text { DBD }(24 \mathrm{kHz}, \\
\text { discharge gap } 5 \mathrm{~mm})\end{array}$} & \multirow[t]{3}{*}{$\begin{array}{l}\mathrm{He}-\mathrm{O} 2(80 \mathrm{~L} / \mathrm{h}-10 \\
\mathrm{L} / \mathrm{h} \text { respectively) }\end{array}$} & \multirow[t]{3}{*}{$1 \mathrm{~h}$} & \multirow[t]{3}{*}{ Direct/ indirect } & $\begin{array}{l}\text {-Decrease in } \\
\text { activity with } \\
\text { exposure time } \\
\text { regardless of } \\
\text { treatment modes }\end{array}$ & \multirow[t]{3}{*}{ (Zhang, Xu, 2015) } \\
\hline & & & & & & $\begin{array}{l}\text {-Less reduction } \\
\text { inenzymatic } \\
\text { activity in the } \\
\text { indirect treatment } \\
\text { for the same time }\end{array}$ & \\
\hline & & & & & & $\begin{array}{l}\text {-Increasein } \\
\text { enzymatic } \\
\text { activity after }\end{array}$ & \\
\hline
\end{tabular}




\section{ACCEPTED MANUSCRIPT}

\begin{tabular}{|c|c|c|c|c|c|c|c|}
\hline & & & & & & storage & \\
\hline & & & & & & $\begin{array}{l}\text {-Recovery trend } \\
\text { after storage ( } 24 \\
\text { h) }\end{array}$ & \\
\hline \multirow[t]{5}{*}{$\begin{array}{l}\text { Glyceraldehyde 3- } \\
\text { phosphate } \\
\text { dehydrogenase(GA } \\
\text { PDH) }\end{array}$} & in vitro: & \multirow[t]{5}{*}{$\begin{array}{l}\text { Microscale plasma } \\
\text { jet }\left(230 \mathrm{~V}_{\text {r.m.s., }} 13.56\right. \\
\text { MHz })\end{array}$} & \multirow[t]{5}{*}{$\mathrm{He}+0.6 \% \mathrm{O} 2$} & \multirow[t]{5}{*}{$600 \mathrm{~s}$} & \multirow[t]{5}{*}{ Direct } & $\begin{array}{l}\text {-Much more } \\
\text { effective } \\
\text { inactivation in } \\
\text { the living cell } \\
\text { than in vitro } \\
\text { conditions }\end{array}$ & \multirow[t]{5}{*}{ (Lackmann, Schneider, 2013) } \\
\hline & $\begin{array}{l}\text { (dissolved in } 1 \\
\mathrm{mg} \\
\mathrm{ml}^{-1} \text { distilled } \\
\text { water and } \\
\text { deride) }\end{array}$ & & & & & \multirow{4}{*}{$\begin{array}{l}\text {-Inactivate } \\
\text { proteins in the } \\
\text { cellular milieu, } \\
\text { physical damage } \\
\text { to the cellular } \\
\text { envelope, } \\
\text { modifications to } \\
\text { DNA and } \\
\text { proteins } \\
\text { contribute to the } \\
\text { bactericidal } \\
\text { properties of } \\
\text { plasma }\end{array}$} & \\
\hline & in vivo: & & & & & & \\
\hline & $\begin{array}{l}\text { E. colias a } \\
\text { model } \\
\text { organisms }\end{array}$ & & & & & & \\
\hline & $\begin{array}{l}\text { (in potassium } \\
\text { phosphate } \\
\text { buffer } \mathrm{pH}: 7.4 \text { ) }\end{array}$ & & & & & & \\
\hline
\end{tabular}

DBD-Dielectric barrier discharge 


\section{ACCEPTED MANUSCRIPT}

Table 4. Overview on studies dealing with the effect of cold plasma on protein structure

\begin{tabular}{|c|c|c|c|c|c|c|c|}
\hline \multirow{2}{*}{$\begin{array}{l}\text { Food component/ } \\
\text { property }\end{array}$} & \multirow[t]{2}{*}{ Matrix } & \multirow[t]{2}{*}{ Plasma Source } & \multicolumn{3}{|c|}{ Treatment Conditions } & \multirow[t]{2}{*}{ Results } & \multirow[t]{2}{*}{ Reference } \\
\hline & & & Gas type & Max time & $\begin{array}{l}\text { Mode of } \\
\text { exposure }\end{array}$ & & \\
\hline \multirow[t]{4}{*}{$\begin{array}{l}\text { Egg white } \\
\text { lysozyme }\end{array}$} & \multirow[t]{4}{*}{$\begin{array}{l}\text { Phosphate buffer } \\
(\mathrm{pH} 7.4)\end{array}$} & \multirow[t]{4}{*}{$\begin{array}{l}\text { low-frequency } \\
\text { plasma jet (13.9 } \\
\mathrm{kHz})\end{array}$} & $\begin{array}{l}\mathrm{He}(0.51 / \mathrm{min})+ \\
\mathrm{O} 2\end{array}$ & \multirow[t]{4}{*}{$30 \mathrm{~min}$} & \multirow[t]{4}{*}{ Direct } & $\begin{array}{l}\text {-Mass shift to } \\
\text { high molecular } \\
\text { weight }\end{array}$ & \multirow[t]{4}{*}{ (Takai, Kitano, 2012) } \\
\hline & & & $(0.15 \mathrm{l} / \mathrm{min})$ & & & -Unfolding & \\
\hline & & & & & & $\begin{array}{l}\text {-Change in the } \\
\text { secondary } \\
\text { structure }\end{array}$ & \\
\hline & & & & & & $\begin{array}{l}\text {-Modification of } \\
\text { some amino acid } \\
\text { side chains (E.g. } \\
\text { cysteine, } \\
\text { phenylalanine, } \\
\text { tyrosine, and } \\
\text { tryptophan) }\end{array}$ & \\
\hline \multirow[t]{2}{*}{$\begin{array}{l}\text { Lactate } \\
\text { dehydrogenase }\end{array}$} & \multirow[t]{2}{*}{$\begin{array}{l}\text { Phosphate buffer } \\
\text { solution (PBS, } \\
\text { pH: 7.5) }\end{array}$} & DBD & \multirow[t]{2}{*}{$\begin{array}{l}\mathrm{He}-\mathrm{O} 2(80 \mathrm{~L} / \mathrm{h}- \\
10 \mathrm{~L} / \mathrm{h} \\
\text { respectively })\end{array}$} & \multirow[t]{2}{*}{$1 \mathrm{~h}$} & \multirow[t]{2}{*}{ Direct/ indirect } & $\begin{array}{l}\text {-Changes in the } \\
\text { secondary } \\
\text { molecular } \\
\text { structure }\end{array}$ & \multirow[t]{2}{*}{ (Zhang, Xu, 2015) } \\
\hline & & $\begin{array}{l}(24 \mathrm{kHz}, \\
\text { discharge gap } 5 \\
\mathrm{~mm})\end{array}$ & & & & $\begin{array}{l}\text {-Polymerization } \\
\text { of the peptide } \\
\text { chains (according } \\
\text { Circular } \\
\text { dichroism and } \\
\text { dynamic light } \\
\text { scattering results) }\end{array}$ & \\
\hline \multirow{3}{*}{$\begin{array}{l}\text { whey protein } \\
\text { isolate } \\
\text { (including } \beta \text { - } \\
\text { lactoglobulin, } \alpha \text { - } \\
\text { lactoalbumin, } \\
\text { and bovine } \\
\text { serum albumin) }\end{array}$} & \multirow[t]{3}{*}{$\begin{array}{l}\text { phosphate buffer } \\
\text { (pH 6.8) }\end{array}$} & \multirow{3}{*}{$\begin{array}{l}\text { DBD }(70 \mathrm{kV}, \\
\text { discharge gap } 44 \\
\mathrm{~mm})\end{array}$} & \multirow[t]{3}{*}{ Air } & \multirow[t]{3}{*}{$60 \mathrm{~min}$} & \multirow[t]{3}{*}{ Direct } & $\begin{array}{l}\text {-Increase in } \\
\text { carbonyl groups }\end{array}$ & \multirow[t]{3}{*}{ (Segat, Misra, 2015) } \\
\hline & & & & & & $\begin{array}{l}\text {-Increase in } \\
\text { surface } \\
\text { hydrophobicity }\end{array}$ & \\
\hline & & & & & & $\begin{array}{l}\text {-Increase in the } \\
\text { size distribution } \\
\text { and the } \\
\text { polydispersity } \\
\text { index }\end{array}$ & \\
\hline \multirow[t]{2}{*}{ Wheat flour } & \multirow[t]{2}{*}{-} & \multirow[t]{2}{*}{$\begin{array}{l}\text { plasma discharge } \\
\text { by DC power } \\
\text { supply }(20 \mathrm{~V}, 9 \\
\mathrm{kHz})\end{array}$} & \multirow[t]{2}{*}{ Air } & \multirow[t]{2}{*}{$120 \mathrm{~s}$} & \multirow[t]{2}{*}{ Direct } & $\begin{array}{l}\text {-No significant } \\
\text { change in the } \\
\text { total protein } \\
\text { levels }\end{array}$ & \multirow[t]{2}{*}{ (Bahrami, Bayliss, 2016) } \\
\hline & & & & & & -Shift towards & \\
\hline
\end{tabular}




\section{ACCEPTED MANUSCRIPT}

\begin{tabular}{|c|c|c|c|c|c|c|c|}
\hline & & & & & & $\begin{array}{l}\text { larger molecular } \\
\text { weight proteins } \\
\text { (SE-HPLC } \\
\text { results) }\end{array}$ & \\
\hline \multirow[t]{3}{*}{$\begin{array}{l}\text { hard and soft } \\
\text { wheat flour }\end{array}$} & \multirow[t]{3}{*}{-} & DBD & \multirow[t]{3}{*}{$\begin{array}{l}\text { Air (45 } \pm 1 \% \\
\text { relative } \\
\text { humidity) }\end{array}$} & \multirow[t]{3}{*}{$10 \mathrm{~min}$} & \multirow[t]{3}{*}{ Direct } & $\begin{array}{l}\text {-Change in the } \\
\text { secondary } \\
\text { structure of } \\
\text { proteins: }\end{array}$ & \multirow[t]{3}{*}{ (Misra, Kaur, 2015) } \\
\hline & & $(70 \mathrm{kV}, 50 \mathrm{~Hz})$ & & & & $\begin{array}{l}\text {-Decrease in } \beta \text { - } \\
\text { sheets }\end{array}$ & \\
\hline & & & & & & $\begin{array}{l}\text {-Increase in } \alpha \text { - } \\
\text { helix and } \beta \text {-turns } \\
\text { (FTIR } \\
\text { spectroscopy } \\
\text { result) }\end{array}$ & \\
\hline \multirow[t]{4}{*}{$\begin{array}{l}\text { Pea protein } \\
\text { isolates (crude } \\
\text { protein content } \\
\mathbf{8 1 . 2 \% )}\end{array}$} & \multirow[t]{4}{*}{$\begin{array}{l}\text { freeze dried and } \\
\text { grinded pea } \\
\text { protein isolate } \\
\text { powder }\end{array}$} & \multirow[t]{4}{*}{$\begin{array}{l}\text { DBD }(8.8 \mathrm{kVPP} \text {, } \\
3.0 \mathrm{kHz})\end{array}$} & \multirow[t]{4}{*}{ Air } & \multirow[t]{4}{*}{$10 \mathrm{~min}$} & \multirow[t]{4}{*}{ Semi-direct } & $\begin{array}{l}\text {-Increase in } \\
\text { water and fat } \\
\text { binding }\end{array}$ & \multirow[t]{4}{*}{ (Bußler, Steins, 2015) } \\
\hline & & & & & & $\begin{array}{l}\text {-Increase in the } \\
\text { protein solubility }\end{array}$ & \\
\hline & & & & & & $\begin{array}{l}\text {-Decrease in } \\
\text { solubility during } \\
\text { storage (except } \\
\text { for an exposure } \\
\text { to CAPP for } 1 \\
\text { min) }\end{array}$ & \\
\hline & & & & & & $\begin{array}{l}\text { - Structural } \\
\text { changes } \\
\text { (Fluorescence } \\
\text { spectra results) }\end{array}$ & \\
\hline \multirow{4}{*}{$\begin{array}{l}\text { glyceraldehyde } \\
\text { 3-phosphate } \\
\text { dehydrogenase( } \\
\text { GAPDH) }\end{array}$} & in vitro: & $\begin{array}{l}\text { Microscale } \\
\text { plasma jet (230 }\end{array}$ & \multirow[t]{4}{*}{$\mathrm{He}+0.6 \% \mathrm{O} 2$} & \multirow[t]{4}{*}{$600 \mathrm{~s}$} & \multirow[t]{4}{*}{ Direct } & \multirow{4}{*}{$\begin{array}{l}\text {-No significant } \\
\text { loss or } \\
\text { fragmentation of } \\
\text { GAPDH in vitro } \\
\text { (assessed by } \\
\text { SDS--PAGE) }\end{array}$} & \multirow[t]{4}{*}{$\begin{array}{l}\text { (Lackmann, Schneider, } \\
\text { 2013) }\end{array}$} \\
\hline & $\begin{array}{l}\text { (dissolved in } 1 \\
\mathrm{mg} \mathrm{ml}^{-1} \text { distilled } \\
\text { water and deride) }\end{array}$ & $\begin{array}{l}\mathrm{V}_{\text {r.m.s., }} 13.56 \\
\mathrm{MHz})\end{array}$ & & & & & \\
\hline & in vivo: & & & & & & \\
\hline & $\begin{array}{l}\text { E. coli as a } \\
\text { model organisms } \\
\text { (in potassium } \\
\text { phosphate buffer } \\
p \mathrm{H}: 7.4 \text { ) }\end{array}$ & & & & & & \\
\hline
\end{tabular}

DBD-Dielectric barrier discharge 


\section{ACCEPTED MANUSCRIPT}

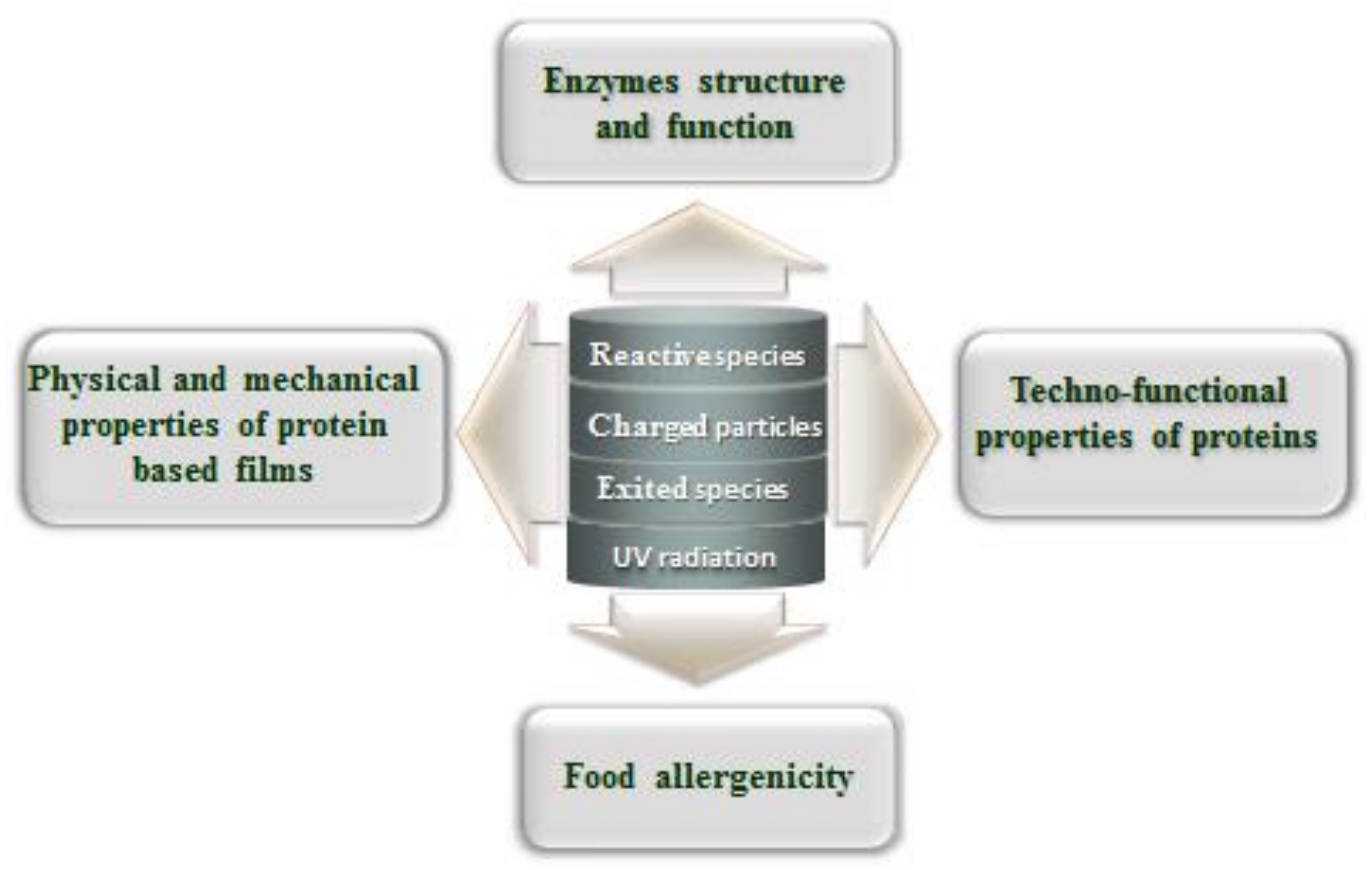

Fig. 1 Research areas in the manipulation of proteins in food systems with cold atmospheric plasma 


\section{ACCEPTED MANUSCRIPT}

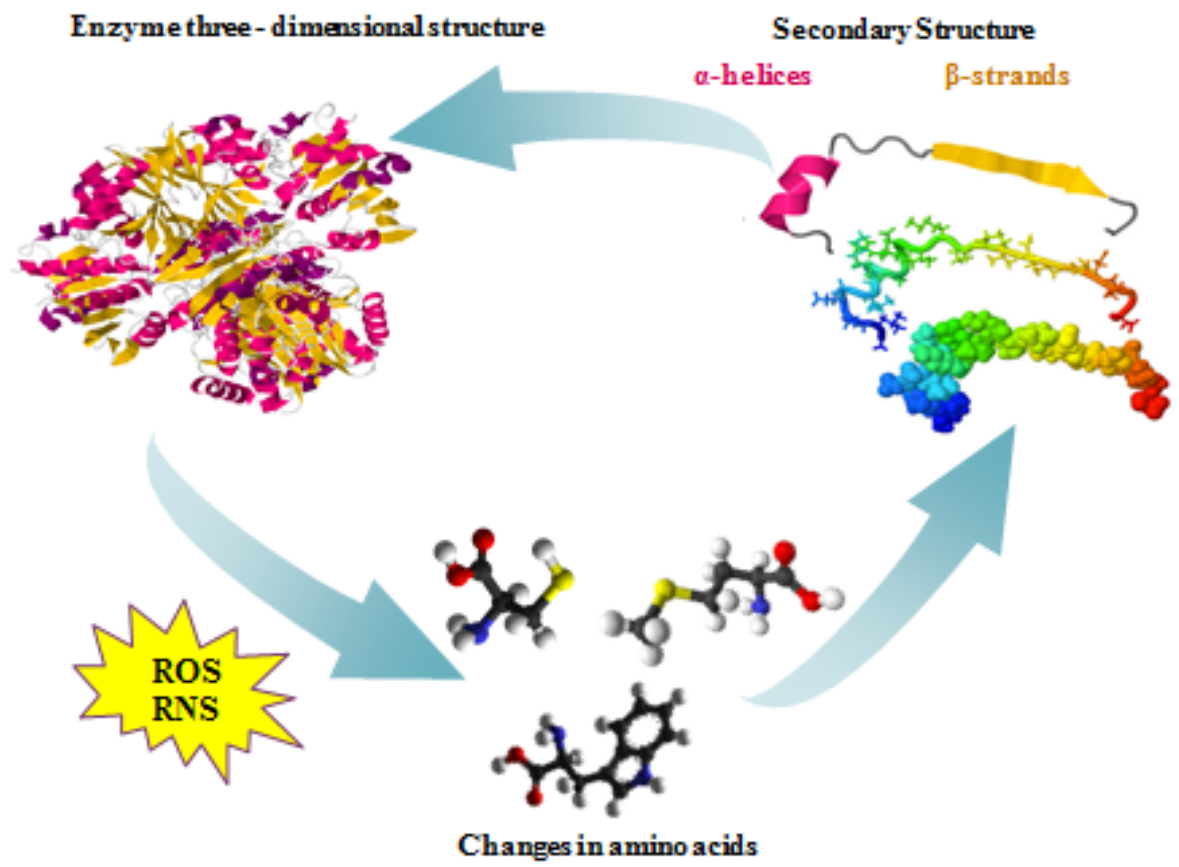

Fig. 2 Schematic of enzyme inactivation by plasma (ROS: Reactive oxygen species, RNS:

Reactive nitrogen species) 